\title{
Bibliographic revision of Mesacanthion Filipjev, 1927 (Nematoda: Thoracostomopsidae) with description of a new species from Jeju Island, South Korea
}

\author{
Raehyuk Jeong ${ }^{1}$, Alexei V Tchesunov ${ }^{\text {Corresp., }}{ }^{2}$, Wonchoel Lee ${ }^{\text {Corresp. } 1}$ \\ 1 Department of Life Science, Hanyang University, Seoul, South Korea \\ 2 Department of Invertebrate Zoology, Faculty of Biology, Moscow State University, Moscow, Russia \\ Corresponding Authors: Alexei V Tchesunov, Wonchoel Lee \\ Email address: avtchesunov@yandex.ru, wlee@hanyang.ac.kr
}

A new species of the genus Mesacanthion Filipjev, 1927 was discovered during a survey of natural beaches of Jeju Island in South Korea. The new species Mesacanthion jejuensis sp. nov., shares general morphology of the genus such as the outer labial and cephalic setae being situated at the middle of cephalic capsule, well-developed mandibles with two columns united by a curved bar, and three equally sized and shaped teeth shorter than the mandibles. The new species belongs to a group of Mesacanthion species which spicules which are shorter than 2 anal body diameter. The new species is most closely related to $M$. pannosum, first discovered in Puget Sound, Washington, in terms of having enlarged cervical setae flap at the end of cephalic capsule, spicules which are shorter than 2 anal body diameter, both supplementary organ and gubernaculum. It can be distinguished from M. pannosum by its stronger inner labial setae, longer outer labial setae, and difference in the index value of $b$ and $c^{\prime}$. Along with the description of Mesacanthion jejuensis sp. nov., the genus Mesacanthion Filipjev, 1927 is bibliographically reviewed and revised. Including the new species, a total of 48 species are described within the genus; 39 which are valid; eight which are considered to be species inquirenda due to misplacement of genus and poor description; one which is considered nomen nudum. An updated diagnosis of the genus is provided along with a compiled tabular key comparing different diagnostic morphological characters of all valid species, as well as a pictorial key consisting of 21 species with spicules shorter than 2 anal body diameters. 


\section{Bibliographic revision of Mesacanthion Filipjev, 1927}

2 (Nematoda: Thoracostomopsidae) with description of

3 a new species from Jeju Island, South Korea

4

5

Raehyuk Jeong ${ }^{1}$, Alexei V. Tchesunov ${ }^{2}$, Wonchoel Lee ${ }^{1}$

6

$7 \quad{ }^{1}$ Department of Life Science, Hanyang University, Seoul, 04763, South Korea

$8 \quad 2$ Department of Invertebrate Zoology, Faculty of Biology, Moscow State University, Moscow,

9 119991, Russia

10

11 Corresponding Authors:

12 Alexei Tchesunov ${ }^{2}$

13 Department of Invertebrate Zoology, Faculty of Biology, Moscow State University, Moscow,

14 119991, Russia

15 Email address: avtchesunov@yandex.ru

16

17 Wonchoel Lee ${ }^{1}$

18 Department of Life Science, Hanyang University, Seoul, 04763, South Korea

19 Email address: wlee@hanyang.ac.kr

20

21 


\section{Abstract}

23 A new species of the genus Mesacanthion Filipjev, 1927 was discovered during a survey of

24

25

26

27

28

29

30

31

32

33

34

35

36

37

38

39

40

41

42

43

44

45

46

47

48

49

50

51

52

53

54

55

56

57

58

59

60

61

natural beaches of Jeju Island in South Korea. The new species Mesacanthion jejuensis sp. nov., shares general morphology of the genus such as the outer labial and cephalic setae being situated at the middle of cephalic capsule, well-developed mandibles with two columns united by a curved bar, and three equally sized and shaped teeth shorter than the mandibles. The new species belongs to a group of Mesacanthion species which spicules which are shorter than 2 anal body diameter. The new species is most closely related to M. pannosum, first discovered in Puget Sound, Washington, in terms of having enlarged cervical setae flap at the end of cephalic capsule, spicules which are shorter than 2 anal body diameter, both supplementary organ and gubernaculum. It can be distinguished from M. pannosum by its stronger inner labial setae, longer outer labial setae, and difference in the index value of $b$ and $c^{\prime}$. Along with the description of Mesacanthion jejuensis sp. nov., the genus Mesacanthion Filipjev, 1927 is bibliographically reviewed and revised. Including the new species, a total of 48 species are described within the genus; 39 which are valid; eight which are considered to be species inquirenda due to misplacement of genus and poor description; one which is considered nomen nudum. An updated diagnosis of the genus is provided along with a compiled tabular key comparing different diagnostic morphological characters of all valid species, as well as a pictorial key consisting of 21 species with spicules shorter than 2 anal body diameters.

\section{Introduction}

Over 50 species of free-living marine nematodes have been reported in South Korea, including those reported on domestic journals (Rho \& Min, 2011; Barnes et al., 2012; Hong \& Lee, 2014; Kim et al., 2015; Hong et al., 2016; Jeong et al., 2019). Majority of the species found in South Korea belong to the family Draconematidae Filipjev, 1918 and other families reported so far includes Comesomatidae Filipjev, 1918, Desmoscolecidae Shipley, 1896, Enchelidiidae Filipjev, 1918 Cyatholaimidae Filipjev, 1918 and Ironidae de Man, 1876. This is the first record of the genus Mesacanthion, let alone the family Thoracostomopsidae Filipjev, 1927 to be recorded in South Korea.

Family Thoracostomopsidae was first erected by Filipjev (1927) and it is composed of three subfamilies: Thoracostomopsinae Filipjev, 1927 (2 genera), Trileptiinae Gerlach \& Riemann, 1974 (1 genus), and Enoplolaiminae De Coninck, 1965 (19 genera). The three subfamilies can be differentiated by the presence or absence of mandibles (Enoplolaiminae or Trileptiinae respectively), with Thoracostomopsinae uniquely bearing a long and eversible spear (Smol \& Coomans, 2006). Now total of 238 species belonging to 22 genera make up the family to date (Bezerra et al., 2019). The genus Mesacanthion Filipjev, 1927 was first erected as a subgenus of Enoplolaimus de Man, 1893 with type species Mesacanthion lucifer (Filipjev, 1927) Gerlach \& Riemann, 1974 discovered from Barents Sea. Filipjev (1927) specified the characters of the genus Mesacanthion to be three short equal (seldom slightly different) onchia, cephalic setae placed in the middle or anterior to the cephalic capsule with tapered tail with a short

Peer) reviewing PDF | (2019:06:38441:1:1:NEW 20 Sep 2019) 
62 dactyli/claviform terminal part. Many of the species currently belonging to the genus

63 Mesacanthion were those transferred from the genus Enoplolaimus when Mesacanthion had

64 been newly erected as a subgenus by Filipjev (1927). Most species (98\%) belonging to this genus

65 are recorded from marine environments with exception to one species (Mesacanthion

66 alexandrinus Nicholas, 1993), which was recorded in freshwater environment. Of the valid

67 species, 40\% (16) were described from Europe; 20\% (8) from America (4 from North and

68 South); 17.5\% (7) from Asia (mainly from western Asia), 15\% (6) from Africa, and 7.5\% (3)

69 from Australia. The genus Mesacanthion is the second most diverse genus in the family next to

70 Enoplolaimus de Man, 1893, with 40 valid species recorded to date.

71 The aim of this study was to review the genus by compiling information such as species

72 distribution, tabular and pictorial key of the genus while determining the validity of existing

73 species. In addition to the revision, Mesacanthion jejuensis sp. nov. is described from Jeju

74 Island, South Korea. An updated diagnosis of the genus is provided with a compiled tabular key

75 consisting of all valid species as well as a pictorial key consisting of 21 species with spicules

76 shorter than 2 anal body diameters.

77

78

Materials and Methods

\section{1) Sampling and morphological study}

80

81

82

83

84

85

86

87

88

89

90

91

92

93

94

95

96

97

98

99

100

101

A series of sampling took place in June 2018, during a survey of natural beaches of Jeju Island, South Korea (Fig. 1). Two sub-samples of the sediments from the intertidal zone were obtained using a $10 \mathrm{~cm}^{2}$ acryl sampling tube. Sediments were fixed in $5 \%$ neutralized formalin solution and brought back to the laboratory. Meiofauna were extracted using the Ludox method (Burgess, 2001), and post-fixed with $70 \%$ ethanol dyed with Rose bengal. Nematodes were counted and individual specimens of interest were picked to a Petri dish filled with $10 \%$ glycerin. The dish was placed in a drying oven set at $40^{\circ} \mathrm{C}$ for a day or two to be completely dehydrated as conferred in the glycerin-ethanol method (Seinhorst, 1959). A single or as many as 5 specimens (depending on their size) were mounted in a single drop of anhydrous glycerin on a glass slide using the wax-ring method (Hooper, 1986). Mounted specimens were identified under Olympus BX51, Leica DM5000B and DM2500 microscopes. All morphometric measurements were done manually using IC measure v.2.0.0.161 software. For scanning electron microscopy, specimens were placed in a drop of glycerin and gradually mixed with drops of distilled water to be washed from any remnant of glycerin. Hydrated specimen were treated to ethanol series for dehydration $(20 \%, 40 \%, 50 \%, 70 \%, 80 \%, 90 \%, 95 \%, 100 \%$, for 10 min each) and then placed in hexamethyldisilazane (HMDS). Specimens bathed in HMDS were placed in a drying oven to be dried. Once dried, specimens were mounted on a stub to be splutter coated, and observed with COXEM EM-30 microscope.

2) Revision of the genus

The Bremerhaven Checklist of Aquatic Nematodes by Gerlach \& Riemann (1974) was used as primary referral when collecting original descriptions/references and additional information on their distribution. Any updates and changes made to the genus subsequent to 1974 were checked 
102 using NeMys, World Database of Nematodes. Once all references had been collected; 1) tabular 103 key consisting of diagnostic characters of all valid species were compiled, 2) distribution of 104 species were determined, 3) validity of each species were determined via comparison and 105 examination, 4) diagnosis of the genus was updated. To construct a pictorial key, original 106 depictions were collected from respective papers and their heads, tails and spicules (if available) 107 were resized and oriented using Adobe Photoshop CS6 for optimum comparison between 108 species. The original drawings were retraced using Wacom Intuous Pro Pen Tablet and Adobe 109 Photoshop CS6.

\section{3) Nomenclatural Acts}

111 The electronic version of this article in Portable Document Format (PDF) will represent a 112 published work according to the International Commission on Zoological Nomenclature (ICZN), 113 and hence the new names contained in the electronic version are effectively published under that 114 Code from the electronic edition alone. This published work and the nomenclatural acts it 115 contains have been registered in ZooBank, the online registration system for the ICZN. The 116 ZooBank LSIDs (Life Science Identifiers) can be resolved and the associated information viewed 117 through any standard web browser by appending the LSID to the prefix http://zoobank.org/. The 118 LSID for this publication is: urn:lsid:zoobank.org:pub: 989DF431-166A-4534-9A37-

119 9AC408194DE7. The online version of this work is archived and available from the following 120 digital repositories: PeerJ, PubMed Central and CLOCKSS.

121

122

123

124

125

126

127

128

129

130

131

132

133

134

135

136

137

138

139

140

141

\section{Abbreviations}

a: body length / maximum body diameter

abd: anal body diameter

b: body length / pharynx length

c: body length / tail length

calc: calculated or measured from published measurements and/or figures

c': tail length / anal body diameter

\section{Systematics}

\section{Order Enoplida Filipjev, 1929}

Family Thoracostomopsidae Filipjev, 1927

Subfamily Enoplolaiminae de Coninck, 1965

Genus Mesacanthion Filipjev, 1927

Generic diagnosis: (Updated from Wieser, 1953; Platt and Warwick, 1983; Smol et al., 2014) Enoplolaiminae. Outer labial and cephalic setae situated at middle or anterior end of cephalic capsule. Mandible well-developed, provided with claws, arch-shaped, consisting of two rod-like columns anteriorly united by a curved bar. Teeth shorter than mandibles. Spicule mostly short, 
142 unipartite and symmetrical, sometimes long, bipartite (divided by a seam: $M$. ditlevseni) and 143 asymmetrical (anisomorphic and anisometric: M. diplechma). If long, usually gubernaculum 144 present with caudal apophysis. Marine and freshwater.

145

146

147

148

149

150

151

152

153

154

155

156

157

158

159

160

161

162

163

164

165

166

167

168

169

170

171

172

173

174

175

176

177

178

179

180

Type species: Mesacanthion lucifer (Filipjev, 1927) Gerlach \& Riemann, 1974.

Notes on generic diagnosis: Mesacanthion, Enoplolaimus de Man, 1893, Paramesacanthion Wieser, 1953, and Oxyonchus Filipjev, 1927 bear mandibles which are arch-shaped, consisting of two rod-like columns while mandibles of Enoploides are solid, two lateral bars fused to form a single rod. Oxyonchus can be distinguished from other genera which bear similar mandibles by its two uniquely large ventrosublateral teeth which extend to anterior end of the mandibles with small dorsal tooth. Mesacanthion, Paramesacanthion, Enoplolaimus, all have teeth shorter than the mandibles, but the latter can be distinguished by the placement of their outer labial and cephalic setae at posterior end of cephalic capsule. Mesacanthion species have their outer labial and cephalic setae at the middle or anterior end of the cephalic capsule, similar to Paramesacanthion species except outer labial and cephalic setae are only in front of anterior end of cephalic capsule. Mesacanthion and Paramesacanthion share the most characters, making them the closest related genera within the family. The two genera can be differentiated from each other however by the following three characteristics: 1 . Outer labial and cephalic setae are located at the anterior end of cephalic capsule for Paramesacanthion while outer labial and cephalic setae are located at the middle or anterior end of cephalic capsule for Mesacanthion. Paramesacanthion species have extra ring(s) of subcephalic setae located at the middle of cephalic capsule where outer labial and cephalic setae would be located for Mesacanthion species. This means when compared to Mesacanthion species, Paramesacanthion species may appear to have extra ring(s) of setae at the anterior end of cephalic capsule, in between inner labial setae and cephalic setae/outer labial setae. This seemingly additional ring of setae are the true cephalic setae, while ring of setae at the middle of cephalic capsule are actually the subcephalic setae for Paramesacanthion species; 2. Sexual dimorphism is apparent in the pilosity of the head for Paramesacanthion species, while it is not apparent in Mesacanthion species; 3. All Paramesacanthion species have spicules consisting of two portions, distal and proximal, articulating from one another, while only some Mesacanthion species (M. audax, M. ditlevseni, M. infantile and M. jejuensis sp. nov.) have bipartite spicules divided by a transversal seam, but without the obvious articulation or constriction.

\section{List of valid species}

1. Mesacanthion africanthiforme Warwick, 1970 (Warwick, 1970: 142-145, fig. 2A-E; three males and three females, Exe estuary, England). 
181

182

183

184

185

186

187

188

189

190

191

192

193

194

195

196

197

198

199

200

201

202

203

204

205

206

207

208

209

210

211

212

213

214

215

216

217

218

219

220

2. Mesacanthion africanum Gerlach, 1957 (Gerlach, 1957b: 4, fig. 3A-C; description based on one male, Atlantic at Congo mouth, plankton net from above muddy ground).

3. Mesacanthion agubernatus Vitiello, 1971 (Vitiello, 1971: 860, fig. 1 A-E; description based on one male, Mediterranean, terrigenous coastal muds, $60 \mathrm{~m}$ deep).

4. Mesacanthion alexandrinus Nicholas, 1993 (Nicholas, 1993: 163, 165, figs. 1A-E, 2A-D; four males and three females, sand at water edge of fresh-water Lake Alexandrina, South Australia).

5. Mesacanthion arabium Warwick, 1973 (Warwick, 1973: 114-116, fig. 14A-G; three males and three females, Arabian Sea, fine sand, $49 \mathrm{~m}$ deep).

6. Mesacanthion arcuatile Wieser, 1959 (Wieser, 1959: 16-17, P1. 11 fig. 11A-B; description based on one female, Alki Beach, Washington, US, 6.5 feet, lapsus arcuatilis).

7. Mesacanthion armatum Timm, 1961 (Timm, 1961: 32, fig. 5A-C; more than one male and one female, Bay of Bengal, on Siphonocladus, lapsus armatus).

8. Mesacanthion audax (Ditlevsen, 1918) Filipjev, 1927 [Ditlevsen, 1918: 208-209, pl. 14 figs. 4, 7, pl. 15 fig. 5 (=Enoplolaimus audax); description based on one male, Øresund, off Aalsgaarde. Filipjev, 1927: 143; transfer Enoplolaimus audax to subgenus Mesacanthion. Gerlach, 1958b: 73; (as Mesacanthion audax), Kiel Bay, Sand and silt, 6 m deep. Riemann, 1966: 186; three males, North Sea, sand].

9. Mesacanthion banale (Filipjev, 1927) Gerlach \& Riemann, 1974 [Filipjev, 1927: 147, P1. 7 fig. 40A, B; (=Enoplolaimus (Mesacanthion) banalis), description based on three females, Barents Sea, muddy sand, 25 m deep. Gerlach \& Riemann, 1947: 531; transfer Enoplolaimus banale to genus Mesacanthion].

10. Mesacanthion breviseta (Filipjev, 1927) Gerlach \& Riemann, 1974 [Filipjev, 1927: 150 151, pl. 7 fig 43A-C; (=Enoplolaimus (Mesacanthion) breviseta) description based on one male and a juvenile male, Barents Sea, sand with shells and stones, $83 \mathrm{~m}$ deep. Gerlach \& Riemann, 1974: 531; transfer Enoplolaimus (Mesacanthion) breviseta to genus Mesacanthion].

11. Mesacanthion cavei Inglis, 1964 [Inglis, 1964: 313-314, figs. 76-78; description based on two males (one in poor condition) and one damaged juvenile, South Africa, coarse sand and broken shells, 26-27 $\mathrm{m}$ deep].

12. Mesacanthion ceeum Inglis, 1964 (Inglis, 1964: 313, figs. 74-75; description based on one male and one juvenile, South Africa, coarse sand and broken shells, $26 \mathrm{~m}$ deep, lapsus ceeus).

13. Mesacanthion conicum (Filipjev, 1918) Filipjev, 1927 [Filipjev, 1918: 105-107, Table 3, fig. 16A-B; (=Enoplolaimus conicus), description based on one female, Black Sea. Filipjev, 1927: 143; transfer Enoplolaimus conicus to subgenus Mesacanthion].

14. Mesacanthion cricetoides Wieser, 1959 (Wieser, 1959: 17-18, fig. 13A-B; description based on one female, Richmond Beach, Washington, 2.5 feet deep).

15. Mesacanthion diplechma (Southern, 1914) Filipjev, 1927 [Southern, 1914: 55-56, fig. 25A-J; (=Enoplus diplechma), two males and two females, Clew Bay, sandy bottom, 25-31 
221

222

223

224

225

226

227

228

229

230

231

232

233

234

235

236

237

238

239

240

241

242

243

244

245

246

247

248

249

250

251

252

253

254

255

256

257

258

259

m deep. Filipjev, 1927: 143; transfer Enoplus diplechma to subgenus Mesacanthion. Gerlach, 1958: 72; as Mesacanthion diplechna, Kiel Bay, silt, 8 m deep. Riemann, 1966: 186; North Sea, sand. Boucher, 1977: 741-743, fig. 4A-E; as Mesacanthion diplechma (Southern, 1914), one male, three females and six juveniles, Pierre Noire (Western Channel), infralittoral sands].

16. Mesacanthion ditlevseni (Filipjev, 1927) Gerlach \& Riemann, 1974 [Filipjev, 1927: 148, pl. 5 fig. 41A-D; (=Enoplolaimus (Mesacanthion) ditlevseni), three males and one female, Barents Sea, silt with stones, 36-280 m deep. Ditlevsen, 1928: 210-213, figs. 8-13; (=Enoplolaimus angustignathus), one male and one female, Greenland, mud, clay, 100-200 m deep, De Coninck and Stekhoven, 1933: 38. Allgén, 1954: 22; (as Enoplolaimus (Mesacanthion) angustignathus), five males and nineteen females, Jan Mayen, Greenland, black sand, 23 m deep. Gerlach \& Riemann, 1974: 532; transfer Enoplolaimus ditlevseni to genus Mesacanthion].

17. Mesacanthion fricum Inglis, 1966 (Inglis, 1966: 87, Figs. 10-12; description based on one male, South Africa, sand, lapsus frica).

18. Mesacanthion heterospiculum Sergeeva, 1974 (Sergeeva, 1974: 123, fig. 4A-B; description based on 14 males, Black Sea, various depths and sediments).

19. Mesacanthion hirsutum Gerlach, 1953 (Gerlach, 1953: 536-537, fig. 9A-E; description based on one male and one female, Mediterranean. Gerlach, 1967: 26, fig. 10A-E; two males, two juveniles and one male, Sarso Island, Red Sea, Saudi Arabia).

20. Mesacanthion infantile (Ditlevsen, 1930) De Coninck \& Schuurmans Stekhoven, 1933 [Ditlevsen, 1930: 205-208, figs. 8-10; (=Enoplolaimus infantilis), one male and one female, Stewart Island, Halfmoon Bay, sand, 5-7 fms. Allgén, 1951: 322-323, fig. 33A-B; (=Enoplolaimus mortenseni), description based on one female, Australia; see Mawson, 1956: 65-66 (re-examination of type specimen=Mesacanthion infantilis), op Wieser, 1953: 75. Allgén, 1951: 323-324, fig. 34A-B; (=Enoplolaimus philippinensis), description based on one juvenile, Australia, op Mawson, 1956: 65-66 (re-examination of type specimen=Mesacanthion infantilis). De Coninck \& Schuurmans Stekhoven, 1933: 38; (as Mesacanthion infantile). Wieser, 1953: 76, fig. 39A-B; two females, Chile. Mawson, 1956: 65-66, fig. 29A-C; two juveniles, Antarctica].

21. Mesacanthion karense (Filipjev, 1927) Gerlach \& Riemann, 1974 [Filipjev, 1927: 152, pl. 7 fig. 45A-C; (=Enoplolaimus (Mesacanthion) karensis), one juvenile male and three females, Kara Sea, sand, 15 m deep. Gerlach \& Riemann, 1974: 533; transfer Enoplolaimus (Mesacanthion) karensis to genus Mesacanthion].

22. Mesacanthion kerguelense Mawson, 1958 (Mawson, 1958: 338-339, fig. 22A-D; five males, two females and three juveniles, Kerguelen Island, Heard Island, Macquarie Island).

23. Mesacanthion longispiculum Gerlach, 1954 (Gerlach, 1954: 228-229, fig. 1A-B; one male and one female, Mediterranean. Gerlach, 1957a: 421; Brazil. Gerlach, 1958a: 352353, fig. 4A-C; (as cf. longispiculum), one male, Mananjary, Madagascar, muddy sand). 
260

261

262

263

264

265

266

267

268

269

270

271

272

273

274

275

276

277

278

279

280

281

282

283

284

285

286

287

288

289

290

291

292

293

294

295

296

297

298

24. Mesacanthion longissimesetosum Wieser, 1953 (Wieser, 1953: 78-79, fig. 42A-E; two males, one female and thirteen juveniles, Chile, littoral exposed and sheltered sand, sublittoral secondary substratum and soft bottom, lapsus longissimesetosus).

25. Mesacanthion lucifer (Filipjev, 1927) Gerlach \& Riemann, 1974 [Filipjev, 1927: 149150, pl. 7 fig. 42A-C; (=Enoplolaimus (Mesacanthion) lucifer), one male and two females, Barents Sea, Kara Sea, sand and sandy silt, 18-83 m deep. Gerlach \& Riemann, 1974: 533; transfer Enoplolaimus (Mesacanthion) lucifer to genus Mesacanthion.]

26. Mesacanthion majus (Filipjev, 1927) Gerlach \& Riemann, 1974 [Filipjev, 1927: 151152, pl. 7 fig. 44A-C; (=Enoplolaimus (Mesacanthion) major), three females, Kara Sea, Barents Sea, sand and gravel, 15-36 m deep. Wieser, 1953: 78, fig. 41A-D; (as Mesacanthion major Filipjev 1925b), four males, two females and 15 juveniles, Arctic Sea, Chile, sublittoral, secondary substratum and coarse bottom, lapsus major. Gerlach \& Riemann, 1974: 533; (as Mesacanthion majus (Filipjev 1927)).]

27. Mesacanthion marisalbi Galtsova, 1976 (Galtsova, 1976: 261-263, fig. 7; two males, one female and one juvenile, White Sea, littoral zone in slightly silted sand).

28. Mesacanthion monhystera Gerlach, 1967 (Gerlach, 1967: 27-28, fig. 11A-F; one male and one juvenile female, Red Sea, sandy beach and littoral subsoil water).

29. Mesacanthion obscurum Gagarin \& Klerman, 2006 (Gagarin \& Klerman, 2006: 533535, fig. 1A-E; twelve males and eight females, Mediterranean Sea off the Israeli coast near Hadera, sandy sediment, 30-35 m deep).

30. Mesacanthion pali Wieser, 1959 (Wieser, 1959: 16, fig. 10A-B; description based on one male, Puget Sound, subterranean water, medium fine to coarse sand).

31. Mesacanthion pannosum Wieser, 1959 (Wieser, 1959: 17, fig. 12A-D; one female and one female, Puget Sound, medium fine to coarse sand, 2.5 feet deep).

32. Mesacanthion propinquum Gagarin \& Klerman, 2006 (Gagarin \& Klerman, 2006: 536538, fig. 2A-E; twelve males and eleven females, Mediterranean Sea off the Israeli coast near Hadera, sandy sediment, 30-35 m deep).

33. Mesacanthion proximum Gerlach, 1957 (Gerlach, 1957a: 427-429, fig. 5G-M; one male and one juvenile, Santos, Brazil, fine sand).

34. Mesacanthion rigens Gerlach, 1957 (Gerlach, 1957a: 427, fig. 5C-F; one male and one female, Bertioga, Brazil. Gerlach, 1956: 204; Brazil, nomen nudum).

35. Mesacanthion southerni Warwick, 1973 (Warwick, 1973: 111-114, figs. 12A-C, 13A-C; six males, three females and two juveniles, Arabian Sea, fine sand and fine muddy sand, 48-49 m deep).

36. Mesacanthion studiosum Inglis, 1964 (Inglis, 1964: 315-316, figs. 79-90; two males, two females and two juveniles, South Africa, coarse white sand, $27 \mathrm{~m}$ deep, lapsus studiosa).

37. Mesacanthion tenuicaudatum (Ssaweljev, 1912) De Coninck \& Schuurmans Stekhoven, 1933 [Ssaweljev, 1912: 111-112; (=Enoplolaimus tenuicaudatus), both sex but number of specimen not specified, White Sea, lapsus tenuicaudatus. De Coninck \& Schuurmans 
Stekhoven, 1933: 39; transfer and correct name from Enoplolaimus tenuicaudatus to Mesacanthion tenuicaudatum].

\section{Mesacanthion virile (Ditlevsen, 1930) De Coninck \& Schuurmans Stekhoven, 1933} [Ditlevsen, 1930: 208-211, fig. 11-14; (=Enoplolaimus virilis), description based on one male, Stewart Island; Halfmoon Bay, New Zealand, Sand, 9.1-12.8 m(converted from fathom). De Coninck \& Schuurmans Stekhoven, 1933: 39; transfer and correct name Enoplolaimus virilis to Mesacanthion virile. Allgén, 1959: 48-50; 8 females and twelve juveniles, Falkland Islands, South Georgia, Graham Land].

\section{Species Inquirenda}

1. Mesacanthion brachycolle Allgén, 1959 [Allgén, 1959: 50, fig. 32A, B; two females and two juveniles, Falkland Islands, sandy bottom with algae, $40 \mathrm{~m}$ deep, Graham Island, mud, 125 m deep. Allgén, 1960: 479, fig 3; (as Enoplolaimus (Mesacanthion) brachycollis), lapsus brachycollis, one female and one juvenile, Falkland Islands]. Species Inquirenda. This species is placed as species inquirenda due to the following reasons: 1) substandard quality of the original text and figures making it impossible to understand, to which genus this species should be referred as; 2) ambiguity of the material, where females and juveniles are indicated as the only materials yet a male tail is given on fig. 32B.

2. Mesacanthion donsitarvae (Allgén, 1935) Wieser, 1953 (species inquirenda) [Allgén, 1935: 47; (=Enoplolaimus donsitarvae) Norway, lapsus (donsi)-tarvae. Wieser, 1953: 76; transfer Enoplolaimus donsitarvae to genus Mesacanthion and opinionates the fact that Allgén provided no figures and description was based on erroneous data of Ditlevsen on wrong number of cephalic setae].

3. Mesacanthion gracilisetosum (Allgén, 1930) Wieser, 1953 (species inquirenda) [Allgén, 1930: 189-191, figs. 1-3; (=Enoplolaimus gracilisetosus), one male, two females and one juvenile, Macquarie Island. Wieser, 1953: 76; transfer Enoplolaimus gracilisetosus to genus Mesacanthion, lapsus gracilisetosus].

4. Mesacanthion hawaiiense (Allgén, 1951) Wieser, 1953 (species inquirenda) [Allgén, 1951: 274-275, fig. 5A-B; (=Enoplolaimus hawaiiensis), description based on one female, Honolulu, Hawaii. Wieser, 1953: 75; transfer Enoplolaimus hawaiiensis to genus Mesacanthion and opinionates description is insufficient, lapsus hawaiiensis].

5. Mesacanthion pacificum (Allgén, 1947) Wieser, 1953 (species inquirenda) [Allgén, 1947: 212, fig. 76A-B; (=Enoplolaimus pacificus), description based on one female and one juvenile, Bay of Panama, Perlas Island. Allgén, 1951: 275, 277, fig. 6A-D; one male, one female and three juveniles, Coast of Honolulu. Wieser, 1953: 66, 76; transfer Enoplolaimus pacificus to genus Mesacanthion and opinionates it resembles Oxyonchus more. Allgén, 1959: 48; (as Mesacanthion pacificus), two juveniles, Falkland Islands, sand and small stones with algae, $40 \mathrm{~m}$ deep, lapsus pacificus]. 
339

340

341

342

343

344

345

346

347

348

349

350

351

352

353

354

355

356

357

358

359

360

361

362

363

364

365

366

367

368

369

370

371

372

373

374

375

376

377

378

6. Mesacanthion paradentatum (Allgén, 1932) Wieser, 1953 (species inquirenda) [Allgén, 1932: 111-112, fig. 8A-B; (=Enoplolaimus paradentatus), description based on one juvenile, Campbell Island. Wieser, 1953: 76; transfer Enoplolaimus paradentatus to genus Mesacanthion, lapsus paradentatus].

7. Mesacanthion primitivum (Allgén, 1929) Wieser, 1953 (species inquirenda) [Allgén, 1929: 441, fig 6A-B; (=Enoplolaimus primitivus), Skagerrak. Wieser, 1953: 76; transfer Enoplolaimus primitivus to genus Mesacanthion, lapsus primitivus].

8. Mesacanthion ungulatum Wieser, 1953 (Wieser, 1953: 78, fig. 40A-B; description based on two juveniles, Seno Reloncavi proper, Chile, exposed littoral algae, lapsus ungulatus). Species inquirenda. Further discussed in the discussion.

\section{Nomen nudum}

1. Mesacanthion microsetosus Allgén, 1932 (nomen nudum - Bezerra et al., 2019) [Allgén, 1932: 110-111, fig. 7A-B; (=Enoplolaimus microsetosus) description based on one juvenile, Campbell Island $40 \mathrm{~m}$ deep. Allgén, 1959: 48; (transfer Enoplolaimus microsetosus to genus Mesacanthion) nine females and five juveniles, South Georgia, Antarctica, clay with sparse stones, $125 \mathrm{~m}$ deep, lapsus microsetosus, nomen nudum]. Only female or juvenile used for description and according to Wieser, 1953, Allgén stating four labial and four cephalic setae makes his description doubtful, Wieser, 1953: 82; moved to Paramesacanthion

\section{Mesacanthion jejuensis sp. nov.}

Figs. 2, 3, Table 1

urn:lsid:zoobank.org:act:EE4EB2FC-59DA-48D3-9C10-C9E5646AF0D9

Type locality: Intertidal zone at coast of Jeju Island, South Korea (3326'05'N $\left.126^{\circ} 55^{\prime} 15^{\prime \prime} \mathrm{E}\right)$, in sandy beach

Type material: All specimen deposited in National Institute of Biological Resources (South Korea). Holotype $1 \delta$ (NIBRIV00008488276) on one slide, Allotype 1 우 (NIBRIV00008488277) on one slide, Paratypes $2 \hat{\jmath}, 1 q$ on two different slides (NIBRIV00008488278-

NIBRIV00008488279), $1 \delta^{\lambda}$ and $1 q$ dried, mounted on two separate stubs and coated with gold for SEM (NIBRIV00008488280- NIBRIV00008488281) from coast of Jeju Island, South Korea (3326'05'N 126 $55^{\circ}$ '15'E) collected on 17 June 2018.

Measurements: See table 1 for detailed measurements and morphometric ratios.

Description: Male (Fig. 2). Cuticle smooth above cephalic capsule, finely striated posterior to cephalic capsule until tail tip. Three lips well developed; edges of lips narrowed and distally 
379 pointy curving outwards, each lips carrying two inner labial setae. Six inner labial setae, stout 380 and conical $12 \mu \mathrm{m}$ long. Six longer outer labial setae and 4 shorter cephalic setae sharing one 381 crown, situated at midlevel of cephalic capsule. Cephalic capsule vaguely set off at mid-level, 382 anterior part narrow, and posterior part gradually thicker. Buccal cavity funnel shaped, wide at 383 anterior end, gradually narrowing to the base. Coffee-bean shaped epidermal glands distributed

384

385

386

387

388

389

390

391

392

393

394

395

396

397

398

399

400

401

402

403

404

405

406

407

408

409

410

411

412

413

414

415

416

417 along dorsal plane from anterior end of body until posterior end. Buccal cavity armed with three mandibles and three teeth. Mandible consisting of two rods distancing from one another anteriorly joined by anterior rod. Lateral edges of each rod with teeth or denticle pointing to the lumen (Fig. 3E). 5-6 short cervical setae in singles at level of posterior end of cephalic capsule. Modified cervical setae, a flap, inverse triangular, just posterior to a single lateral outer labial setae at posterior end of cephalic capsule, observable in all four males on both lateral body sides (Fig. 4B). Amphid ambiguously present below the cervical flap, pouch-shaped. Two pores observed diagonally below cervical flap and amphid (Fig. 4B). Cervical somatic setae in 8 groups of 2-3 around pharyngeal region a, roughly two cephalic capsule lengths below level of cephalic capsule end (Fig. 4A, B). Some cervical setae partly possessing irregular lateral and terminal processes, resembling penicillus or plumule (Figs. 4A, B). Somatic setae scarcely distributed along the body in singles until tail region. Pharynx fairly long and annulated with plasmatic lens-like interlayers and sinuous external contours, cardia triangular and going into the middle of intestine. Metanemes not visible. Testes paired opposed, both ends situated to the right of the intestine. Thick supplement, $18 \mu \mathrm{m}$ long, $165 \mu \mathrm{m}$ above from cloacal opening. Spicules paired, bipartite, symmetrical, curved slightly and thick. Each spicule with distinct transverse, oblique seam, dividing it distal and proximal portions (Figs. 5A, B). Distal portion shorter than proximal portion. Distal portion slightly curved towards cloacal opening, anterior end with one denticle just above and/away from its round pointy end. Proximal portion rather straight, posterior end with a knob/neck-like constriction. Gubernaculum embracing spicules, shaped like irregular triangle, lateral end which lies lateral to the spicule, almost perpendicular to axis of the anus, even extending beyond distal end of spicule, and the other end arching off at an angle towards the tail. Tail elongated and papilliform. 5 somatic setae in tail region. Caudal gland protruded anterior to the anus, their nucleus-containing bodies located along the posterior midgut. Spinneret well developed. 1 short caudal (terminal) setae (with porous) just above distal end of tail.

Female (Fig. 3). Female generally longer and larger in size. Three lips higher in female, edges of lips noticeably stronger in female, distal end aggressively curved, each lips carrying two inner labial setae. No subtle sexual dimorphism found in setae in the head region, other than shorter length outer labial and cephalic setae compared to male. Short knobs on each anterior end of mandible. Female lacking cervical setae flap on cephalic capsule end. Amphid not observed. Groups of cervical setae found in esophageal region in males are in singles as opposed to doubles/trios (Fig. 5D). Vulva located at $55 \%$ of total body length with protruding lips. Reproductive system didelphic amphidelphic, both ends flexed inwards. Both ovaries positioned 
418 left of the intestine, antidromously reflexed. Tail conico-cylindrical, 3 somatic setae in tail region 419 with no apparent caudal setae.

420

421

422

423

424

425

426

427

428

429

430

431

432

433

434

435

436

437

438

439

440

441

442

443

444

445

446

447

448

449

450

451

452

453

454

455

456
Diagnosis: Mesacanthion. Body length $2700-4630 \mu \mathrm{m}$. Cuticle finely striated along the body, smooth only in cephalic capsule region, head set off with cephalic capsule. Metanemes not visible. Six inner labial setae 8-15 $\mu \mathrm{m}$. Six longer outer labial setae 36-59 $\mu \mathrm{m}$, four shorter cephalic setae 18-34 $\mu \mathrm{m}$ long sharing one crown. Buccal cavity armed with mandible and three teeth. Mandible consisting of two rods distancing from one another anteriorly joined by anterior rod. Lateral edges of each rod with teeth or denticle pointing to the lumen. Buccal cavity 37-61 $\mu \mathrm{m}$ long. 8-9 groups of cervical setae in groups of two to three at stoma region. Cervical setae in single groups in females. Males with testis paired and opposed. Spicule paired, symmetrical, slightly curved, divided into two portions by a seam. Distal portion shorter than proximal. Proximal portion with knob/neck-like end. Gubernaculum paired, shaped like an irregular triangle with caudal apophysis, distal end extending beyond spicules and ventrally towards cloacal opening. Precloacal supplementary organ present. Three to four somatic setae distributed along the tale. Tail conico-cylindrical, c' 4-5.7, cylindrical portion of the tail constituting about $30 \%$ of the entire tail length.

Differential diagnosis: Total of 23 species of Mesacanthion with spicules shorter than 2 abd were examined. Species such as $M$. arcuatile, M. conicum and M. cricetoides were omitted from examination due to the fact that only female was ever described. Also, species with asymmetrical spicules (anisomorphic and anisometric) were omitted even if the shorter spicule is shorter than 2 abd, since Gagarin \& Klerman (2006) already provided a key for those group of species. $M$. tenuicaudatum which most likely does have spicules shorter than 2 abd, is also omitted from examination and pictorial key as there are no depiction of the specimen available. Description also lacks information regarding gubernaculum, measurements of anal body diameter and length of all setae, making it not feasible for comparison. Lastly, M. virile is included for analysis, despite its lack of information on abd. Although it cannot be confirmed that it possesses spicules which are shorter than 2 abd, given the length of spicule and other relative body measurements, it is likely that this species belongs to this group.

The new species is most similar to M. pannosum as they both share striking resemblance in overall morphology. They both have spicules shorter than 2 abd with presence of both supplementary organ and gubernaculum. Index value of both species (a and c) are within range to each other as well. Most interesting character shared by the two species is the presence of modified/transformed cervical setae seen as a flap. This flap-like appendage is seen as inverse triangle just below a single outer labial seta (lateral seta), at the end of cephalic capsule. It was first observed by Wieser (1959) in males of M. pannosum and it has been a character unique to the species until it now. Like M. Pannosum, the flap is also observed only in males of the new species, and the morphology is in line with those previously seen in M. pannosum. The only

Peer) reviewing PDF | (2019:06:38441:1:1:NEW 20 Sep 2019) 
457 458

459

460

461

462

463

464

465

466

467

468

469

470

471

472

473

474

475

476

477

478

479

480

481

482

483

484

485

486

487

488

489

490

491

492

493

494

495

496

difference concerning the flap between the two species is that M. pannosum had two flaps next to each other, but only a single flap is seen in the new species (Fig. 4B).

The new species differs from $P$. pannosum by having stronger (stout) inner labial setae; longer outer labial setae (43-59 $\mu \mathrm{m}$ vs. 24-25 $\mu \mathrm{m}$, respectively); difference in the index value of $\mathrm{b}$ and c' (4.5-5 vs. 6.3 and 4.0-5.7 vs. 3, respectively); type of spicules (unipartite vs. bipartite with seam, respective).

The validity of diagnostic value in presence or absence of a seam (bipart spicule), can be questionable considering it is an ambiguous character and could be mistaken from a diffraction caused by a large gubernaculum. Due to this reason, the seam was not given a significant importance in the diagnosis of species within the genus, but the character and species which bear it are still discussed for reference.

Total of four species within the genus Mesacanthion have paired bipartite spicules: M. audax, M. ditlevseni, M. infantile, and M. jejuensis sp. nov. They all have spicules which are shorter than 2 abd, but M. audax is most easily distinguished from the other three species by its lack of supplementary organ. While the three species have supplementary organ, the new species resembles $M$. ditlevseni the most. They both have stout inner labial setae with presence of both supplementary organ and triangular gubernaculum. Their index value (a, b, and c') are also within range from one another. The new species can be distinguished by its proportionally longer cephalic setae (in which is double the length of cephalic setae observed in M. ditlevseni); presence of cervical flap in new species; dense distribution of cervical setae in groups of doubles/trios below at stoma region in male; differing details to its spicules and gubernaculum. The spicule of the new species is different from $M$. ditlevseni in that distal portion of the spicule is shorter than proximal portion where vice versa is true for $M$. ditlevseni. This is peculiar characteristic unique to the new species, as all bipartite spicules found in Mesacanthion species have longer distal portion over proximal portion. We believe that diagnostic value of modified cervical setae flap is greater than bipartite spicule (spicule with seam) in terms of ambiguity. Therefore, the species most similar to the new species is considered to be M. pannosum.

Etymology: The species name jejuensis is given as the species was discovered from coast Jeju Island, South Korea.

Pictorial key to species with spicules shorter than 2 anal body diameter within the genus Mesacanthion and morphometric values for valid species of Mesacanthion

Fig. 6-8, Table 2

Key to species with spicules shorter than 2 anal body diameters within the genus Mesacanthion

1. Supplementary organ present in males ... 5

-Supplementary organ absent in males ... 2 
497 2. Stout post-cloacal setae present ... M. africanthiforme

498 -Stout post-cloacal setae absent ... 3

499 3. Tail conico-cylindrical ... M. karense

500 -Tail conical ... 4

501 4. Tail long $(\mathrm{c}=14-19)$ with typical stoma ... M. audax

502 -Tail stout ( $c=43-51)$ with well-developed posterior rods of the stoma ... M. armatum

503 5. Gubernaculum present in males ... 11

504 -Gubernaculum absent in males ... 6

505 6. Body length over $3000 \mu \mathrm{m} \ldots 7$

506 -Body length below $2000 \mu \mathrm{m} \ldots 8$

507 7. Several cervical setae at cephalic capsule with spicules arrow shape with sharp distal end ...

508 M. agubernatus

509 -No cervical setae at cephalic capsule with simple spicules slightly curved with blunt distal end

510 ... M. studiosum

511 8. Mandible decorated by longitudinal marks ... M. rigens

512 -Mandible with no decoration ... 9

513 9. Somatic setae absent ... M. proximum

514 -Somatic setae present ... 10

515 10. Dorsal tooth missing ... M. monhystera

516 -Dorsal tooth present ... M. hirsutum

517 11. Enlarged cervical setae (flaps) present below lateral outer labial seta at posterior end of

518 cephalic capsule ... 12

519 -Enlarged cervical setae (flaps) absent ... 13

520 12. Inner labial setae stout. Index c' 4.0-5.7 ... M. jejuensis sp. nov.

521 -Inner labial setae thin. Index c' 3 ... M. pannosum

522 13. Subventral setae absent ... 14

523 -Subventral setae present ... 18

524 14. Gubernaculum triangular ... 15

525 -Gubernaculum simple with dorsal appendage ... M. marisalbi

526 15. Gubernaculum with two parts; membranous part and rod-like part which supports it caudally

527 with barbed tip ... M. virile

528 -Gubernaculum with just one part ... 16

529 16. Spicule bipartite ... M. ditlevseni

530 -Spicule unipartite ... 17

531 17. Subcephalic setae absent, supplementary organ 2.2 abd away from anus ... M. breviseta

532 -Four subcephalic setae very thin near end of cephalic capsule, supplementary organ 3 abd away

533 from anus ... M. lucifer

534 18. Proximal end of spicule with massive process ... M. fricum

535 -Proximal end of spicule without massive process ... 19

536 19. Distal end of spicule with backwardly pointing spines ... M. audax 
537 -Distal end of spicule with no backwardly pointing spines ... 20

538 20. Spicule distally dilated ... M. majus

539 -Spicule with no dilation ... 21

540 21. Supplementary organ located close ( 1 spicule length) to proximal end of the spicule $\ldots M$.

541 kerguelense

542 -Supplementary organ located further ( $>1.1$ spicule length) away from the anus ... 22

543 22. Inner labial setae stout $12 \mu \mathrm{m}$ long, Index a $\sim 30$, Index $\mathrm{b} \sim 5$, Index c' $4.2-4.5 \ldots M$.

544 longissimesetosum

545 -Inner labial setae stout $24 \mu \mathrm{m}$ long, Index a $\sim 50$, Index $\mathrm{b} \sim 3$, Index c' $2.8 \ldots$. M. pali

546

547 Discussion

548 The genus Mesacanthion currently consist of 39 valid species. Of these valid species,

549 Mesacanthion ungulatum Wieser, 1953 is most ambiguous in terms of validity. The species was

550 erected from a description based on only two juvenile specimens, with reasoning that the species

551 in question bears extremely long labial setae and high lips. While there is no problem with the

552 validity according to the International Code of Zoological Nomenclature, since a new species can

553 be described at any life stage, it is ambiguous nonetheless in its current state as its distinguishing

554 characters for the species is no longer unique to the species. Labial setae in M. ungulatum is

555 noted to be extremely long, measuring to be $15 \mu \mathrm{m}$ might have been lengthy for the genus at the

556 time of original description, but currently compared to other species within the genus, it is quite

557 average in length. Mesacanthion arabium Warwick, 1973 bears labial setae measuring from 23-

$55825 \mu \mathrm{m}$, albeit its overall longer body length. Even when comparing proportionally to body

559 length, Mesacanthion fricum Inglis, 1966 (body length $1650 \mu \mathrm{m} /$ length of inner labial setae 13

$560 \mu \mathrm{m})$ and Mesacanthion hirsutum Gerlach, $1953(1155-1982 \mu \mathrm{m} / 8-14 \mu \mathrm{m})$ have longer

561 proportioned inner labial setae than M. ungulatum $(2250-2430 \mu \mathrm{m} / 15 \mu \mathrm{m})$. The only

562 characteristic discerning this species from the rest is then by its high lips, but even that is

563 questionable, considering later described species such as Mesacanthion alexandrinus Nicholas,

564 1993, while it does not mention in the description, depict just as high lips as shown in $M$.

565 ungulatum. It would be appropriate to consider this a synonymization case, and find a species

566 described after M. ungulatum which is most similar to follow the Principle of Priority.

567 Unfortunately, remaining characteristics of M. ungulatum is very generic to the genus and the

568 fact that there is no male to compare its spicules, gubernaculum and supplementary organ which

569 can be unique to each species, no further action can be taken other than to place it as species

570 inquirendum. There is however $18 \mathrm{~S}$ ribosomal RNA gene, partial sequence of M. ungulatum

571 available on GenBank. It seems that the sample specimen was obtained from Chile, the type

572 locality, so there is high probability that more information can be gathered regarding adult stage

573 of this species. Hopefully someone can review the species with a sound adult specimen to clear

574 this species of its current status.

575 Diagnosis of the genus Mesacanthion provided by Smol et al. 2014, was updated in this

576 study based on our review and findings. The original diagnosis specifically states that spicules 
577 are generally short, but if long, gubernaculum with caudal apophysis is to be present. This is true 578 in most cases, but with exceptions in species such as M. brevista, which has one of the longest 579 spicules in the genus $(165 \mu \mathrm{m})$ with no gubernaculum at all, and M. arabium, which has a pair of 580 short spicules $(24 \mu \mathrm{m})$ bearing a triangular gubernaculum which resembles a caudal apophysis.

581 In addition, accounts for different types of spicules were added (symmetric/asymmetric,

582 bipartite, etc), so that later encounters of new species with bipartite spicules is not simple

583 mindedly mistaken as Paramesacanthion as opposed to Mesacanthion, as was the case with us.

584 The morphology of the spicule is especially diverse in the genus Mesacanthion. Spicules

585

586

587

588

589

590

591

592

593

594

595

596

597

598

599

600

601

602

603

604

605

606

607

608

609

610

611

612

613

614

615

616 which come in a pair can be either short or long/symmetrical or asymmetrical/straight, L-shaped or arcuate in shape. Spicules, if long can be anisomorphic and/or anisometric and can be bipartite or in whole. The part of it being bipartite can be perplexing when it comes to species identification, as it can lead to wrongful placement of the species to the related genus Paramesacanthion. Diagnosis of Paramesacanthion provided by Smol et al. 2014 specifically mentions its distinguishing characteristic is "spicules consisting of two portions, distal and proximal, articulating with each other", while diverse nature of spicules in Mesacanthion is missing in its diagnosis. Even while knowing some spicules in Mesacanthion can be bipartite, it is imperative to put emphasis into the word "articulating" in diagnosis of Paramesacanthion species' two portioned spicules. Most spicules of the genus Paramesacanthion clearly depict the two portions and its articulation from one another (i.e. Knee joint). While some species like $P$. marei, does not clearly show the articulation much like bipartite spicules found in Mesacanthion, they too can be distinguished as a Paramesacanthion species by its: 1. Outer labial and cephalic setae in front of anterior end of cephalic capsule and 2. Subcephalic setae at middle of cephalic capsule. Paramesacanthion species bear an extra ring of subcephalic setaes which can be confused with the true cephalic setae of Mesacanthion species. Wieser (1953) specifically mentioned this when erecting the genus, not to confuse "the subcephalic setae of the male with the true cephalic setae since the former occupy that level of the head on which in Mesacanthion the insertion of the cephalic setae takes place" (p.80). As such, the new species has a paired spicule which are symmetric from one another. They are bipartite with distal portion slightly shorter than proximal part. Distal and proximal is divided by a seam which seems to thicken or "arm" around the distal portion of the spicule. Proximal end arcuate and distal end set with pointing spine or a "barb".

Metanemes are one character which was surprisingly not observed within the new species. While no species belonging to Mesacanthion have yet been described to date with description or depiction of metanemes, orthometaneme of dorsolateral kind was expected to be present within the new species prior to inspection. Diagnosis of the family Thoracostomopsidae Filipjev, 1927 (according to Smol et al. 2014) specifically states "only dorsolateral orthometanemes with a robus scapulus but no caudal filament". Species belonging to Mesacanthion's most closely related genus, Paramesacanthion abyssorum Bussau 1995, was also recorded with presence of dorsolateral orthometanemes. Not only that, "coffee bean shaped epidermal glands" which were sighted alongside dorsolateral orthometanemes in P. abyssorum 
617 are very much present within the new species as well (Figs. 2A, 3A). Given that orthometanemes 618 are subtler in their appearance compared to loxometanemes, it is quite possible that even other 619 species of Mesacanthion already described, could have had them present. Despite it being more 620 difficult to spot in older types due to their conditions, it'll be important for future descriptions of 621 any species belonging to the family Thoracostomopsidae to identify their metanemes.

622 After discovering the new species, the type locality was visited twice more in August and 623 November of 2018, to obtain alcohol samples of the specimen for molecular analysis. While the 624 efforts were unfortunately fruitless until now, we are hopeful that we will get the required 625 specimen for additional molecular analysis in the future. It'll be interesting to compare the 626 relationship between close related species by the means of molecular phylogenetic data.

627

628

\section{Conclusion} The discovery of Mesacanthion jejuensis sp. nov., has led to number of findings: (1) the new species closely related to M. pannosum, in terms of general morphology (bearing precloacal supplementary organ and gubernaculum) and having modified cervical setae flap. (2) the new species, like three other species within the genus (M. audax, M. ditlevseni, M. infantile), has a pair of bipartite spicule. (3) the diagnosis of the genus Mesacanthion has been updated to account for diverse nature of spicules. (4) the genus Mesacanthion has been reviewed and revised, transferring two species, M. brachycolle and M. ungulatum to species inquirenda, updating the total number of valid species to 39 species. While we were unable to obtain genetic data for the new species, further efforts will be made in order to investigate the phylogenetic relationship and placement of species within the genus Mesacanthion.

639

\section{0}

641

\section{Acknowledgements}

We thank Vadim Mokievsky (P.P. Shirshov Institute of Oceanology) and Jungho Hong for and one anonymous reviewer for their careful reading of our manuscript which greatly improved this manuscript.

647 Allgén, C.A. (1929) Neue freilebende marine Nematoden von der Westküste Schwedens. Zoologische Jahrbucher (Systematik), 57 (5), 431-496.

650

Allgén, C.A. (1930) Über eine neue Art des Genus Enoplolaimus de Man, Enoplolaimus gracilisetosus von der Macquarieinsel. Zoologischer Anzeiger, 92, 189-191.

Allgén, C.A. (1932) Weitere Beiträge zur Kenntnis der marinen Nematodenfauna der Campbellinsel. Nyt Magasin for Naturvidenskaberne, 70, 97-198.

Allgén, C.A. (1935) Zur Kenntnis norwegischer Nematoden. V. Weitere neue oder wenig bekannte freilebende marine Nematoden aus der Strandzone bei Tarva. Det Konglige Norske Videnskabers Selskab Forhandlinger, 8 (15), 47-50. 
656

657

658

659

660

661

662

663

664

665

666

667

668

669

670

671

672

673

674

675

676

677

678

679

680

681

682

683

684

685

686

687

688

689

690

691

692

693

694

Allgén, C.A. (1947) West American Marine Nematodes. (Papers from Dr. Th. Mortensen's Pacific Expedition 1914-16. 75). Videnskabelige Meddelelser Dansk Naturhistorisk Forening i Kjöbenhavn, 110, 65-219.

Allgén, C.A. (1951) Pacific Freeliving Marine Nematodes. (Papers from Dr. Th. Mortensen's Pacific Expedition 1914-16. LXXVI). Videnskabelige Meddelelser Dansk Naturhistorisk Forening $i$ Kjöbenhavn, 113: 263-411.

Allgén, C.A. (1954) Freeliving marine nematodes from East Greenland and Jan Mayen (The Swedish Greenland Expedition 1899). Meddelelser om Grønland, 107 (6), 1-44.

Allgén, C.A. (1959) Freeliving marine nematodes. Further zoological results of the Swedish Antarctic expedition 1901-1903, 5 (2), 1-293.

Allgén, C.A. (1960) Antarktische meistens neue freilebende marine Nematoden aus dem Graham-Land. Zoologischer Anzeiger, 164, 474-499.

Barnes, N., Kim, H. \& Lee, W. (2012) New species of free-living marine Sabatieriinae (Nematoda: Monhysterida: Comesomatidae) from around South Korea. Zootaxa, 3368, 263-290. https://doi.org/10.11646/zootaxa.3368.1.14

Bezerra, T.N., Decraemer, W., Eisendle-Flöckner, U., Hodda, M., Holovachov, O., Leduc, D., Miljutin, D., Mokievsky, V., Peña Santiago, R., Sharma, J., Smol, N., Tchesunov, A., Venekey, V., Zhao, Z. \& Vanreusel, A. (2019) Nemys: World Database of Nematodes. Accessed from: http://nemys.ugent.be (accessed 26 May 2019) https://doi.org/10.14284/366

Boucher, G. (1977) Nématodes des sables fins infralittoraux de la Pierre Noue (Manche occidentale). IV. Enoplida. Bulletin du Muséum National d'histoire naturelle, Zoologie, $325,733-752$.

Burgess, R. (2001) An improved protocol for separating meiofauna from sediments using colloidal silica sols. Marine Ecology Progress Series, 214, 161-165. https://doi.org/10.3354/meps214161

De Coninck, L.A. \& Schuurmans Stekhoven, J.H. (1933) The freeliving marine nemas of the Belgian Coast. II With general remarks on the structure and the system of nemas. Mémoires du Musée royal d'histoire naturelle de Belgique, 58, 3-163.

de Man, J.G. (1876) Onderzoekingen over vrij in de aarde levende Nematoden. Tijdschrift Nederlandsche Dierkundig Vereeiging, 2, 78-196.

de Man, J.G. (1893). Cinquième Note sur les Nématodes libres de la mer du Nord et de la Manche. Mémoires de la Société zoologique de France, 6, 81-125.

Ditlevsen, H. (1918) Marine freeliving nematodes from Danish waters. Videnskabelige Meddelelser fra Dansk Naturhistorisk Forening i Kjøbenhavn, 70, 147-214.

Ditlevsen, H. (1928) Free-living marine Nematodes from Greenland Waters. Meddelelser om Grønland Supplement, 27, 199-250.

Ditlevsen, H. (1930) Marine free-living nematodes from New Zealand. Videnskabelige Meddelelser fra Dansk Naturhistorisk Forening i Kjøbenhavn, 87, 201-242.

Peer] reviewing PDF | (2019:06:38441:1:1:NEW 20 Sep 2019) 
695 Filipjev, I.N. (1918) Free-Living Marine Nematodes of the Sevastopol Area. Transactions of the

696

697

698

699

700

701

702

703

704

705

706

707

708

709

710

711

712

713

714

715

716

717

718

719

720

721

722

723

724

725

726

727

728

729

730

731

732

733 Zoological Laboratory and the Sevastopol Biological Station of the Russian Academy of Sciences. Series II, N4, (Issue I \& II). (Translated from Russian).

Filipjev, I.N. (1927) Les Nematodes libres des mers septentrionales appurtenant a la famille des Enoplidae. Archiv für Naturgeschichte, 91A (6), 1-216.

Gagarin, V.G. \& Klerman, A.K. (2006) Two new species of Mesacanthion Filipjev, 1927 (Nematoda: Enoplida) from the Mediterranean Sea. Nematology, 8 (4), 533-538. https://doi.org/10.1163/156854106778614001

Galtsova, V.V. (1976) Free-living marine nematodes as a component of the meiobenthos of Chupa Inlet of the White Sea. Issledovanija fauni morjei (Nematody i ikh Rol' v Meiobentose), 17 (25), 165-272 (in Russian).

Gerlach, S.A. (1953) Die Nematodenbesiedlung des Sandstrandes und des Küstengrundwassers an der italienischen Küste I. Systematischer Teil. Archivio Zoologico Italiano, 37, $517-$ 640.

Gerlach, S.A. (1954) Nématodes marins libres des eaux souterraines littorals de Tunisie et d'Algérie. Vie Milieu, 4 (2), 221-237.

Gerlach, S.A. (1956) Die Nematodenbesiedlung des tropischen Brandungsstrandes von Pernambuco. Brasilianische Meeres-Nematoden II. Kieler Meeresforsch, 12, 202-218.

Gerlach, S.A. (1957a) Die Nematodenfauna des Sandstrandes an der Küste von Mittelbrasilien (Brasilianische Meerse-Nematoden IV). Mitteilungen aus dem Zoologischen Museum in Berlin, 33 (2), 411-459.

Gerlach, S.A. (1957b) Marine Nematoden von der Kongo-Mündung. Bullitin del'Institut Royal des Sciences Naturelles de Belgique, 33 (28), 1-16.

Gerlach, S.A. (1958a) Deuxième contribution à la faune des Nématodes des eaux interstitielles littorales de Madagascar. Mém. Inst. scient. Madagascar, (F) 2, 343-365.

Gerlach, S.A. (1958b) Die Nematodenfauna der sublitoralen Region in der Kieler Bucht. Kieler Meeresforsch, 14, 64-90.

Gerlach, S.A. (1967) Freilebende Meeres-Nematoden von dan Sarso-Inseln (Rotes Meer) 3. Beitrag der Arbeitsgruppe Litoralforschung. "Meteor" Forschungsergebnisse, Series D (2), 19-43.

Gerlach, S.A. \& Riemann, F. (1974) The Bremerhaven checklist of aquatic nematodes. A catalogue of Nematoda Adenophorea excluding the Dorylaimida. Part 2. Veröffentlichungen des Instituts für Meeresforschung in Bremerhaven, Supplement 4, 405-736

Hodda, M. (2007) Phylum Nematoda. Zootaxa, 1668, 265-293. https://doi.org/10.11646/zootaxa.1668.1.14

Hong, J.H. \& Lee, W. (2014) Two new species of free-living marine nematodes (Nematoda: Oncholaimida: Enchelidiidae) from Maemul Island, Korea. Zootaxa, 3785 (3), 419-437. https://doi.org/10.11646/zootaxa.3785.3.5

Peer] reviewing PDF | (2019:06:38441:1:1:NEW 20 Sep 2019) 
734

735

736

737

738

739

740

741

742

743

744

745

746

747

748

749

750

751

752

753

754

755

756

757

758

759

760

761

762

763

764

765

766

767

768

769

770

771

772

Hong, J.H., Tchesunov, A.V. \& Lee, W. (2016) Revision of Cervonema Wieser, 1954 and Laimella Cobb, 1920 (Nematoda: Comesomatidae) with descriptions of two species from East Sea, Korea. Zootaxa, 4098 (2), 333-357. https://doi.org/10.11646/zootaxa.4098.2.7 Hooper, D. (1986) Handling, fixing, staining and mounting nematodes. In: Laboratory Methods for Work with Plant and Soil Nematodes. Ministry of Agriculture, Fisheries and Food, Her Majesty's Stationery Office, London, pp. 59-80.

Inglis, W.G. (1964) The marine Enoplida (Nematoda): a comparative study of the head. Bulletin of the British Museum (Natural History) Zoology, 11, 265-376.

Inglis, W.G. (1966) Marine nematodes from Durban, South Africa. Bulletin of the British Museum (Natural History) Zoology, 14, 81-106.

Jeong, R., Tchesunov, A.V. \& Lee, W. (2019) A new species of the genus Thalassironus (Nematoda: Enoplida: Ironidae) from the coasts of South Korea. Zootaxa, 4563 (3), 516530. https://doi.org/10.11646/zootaxa.4563.3.6

Kim, H., Tchesunov, A.V. \& Lee, W. (2015) A new species of the genus Marylynnia (Nematoda: Chromadorida: Cyatholaimidae) from Gwangyang Bay, Korea. Proceedings of the Biologcal Society of Washington, 128 (4), 227-238. https://doi.org/10.2988/0006324X-128.4.227

Mawson, P.M. (1956) Free-living nematodes. Section I: Enoploidea from Antarctic stations. B.A.N.Z. Antarctic Research Expedition Reports, Series B, 6 (3), 37-74.

Mawson, P.M. (1958) Free-living nematodes. Section 3: Enoploidea from subantarctic stations. B.A.N.Z. Antarctic Research Expedition Reports, Series B, 6 (14), 307-358.

Nicholas, W.L. (1993) Two new species of nematode (Nematoda: Enoplida: Thoracostomopsidae) from Lake Alexandrina, South Australia. Transactions of the Royal Society of South Australia, 117 (4), 163-170.

Platonova, T.A. \& Galtsova, V.V. (1976) Nematodes and their role in the meiobenthos. Akad. Nauk (Zool. Inst.), Moscow, pp. 1-366., available online at https://archive.org/details/nematodestheirro00plat

Platt, H. \& Warwick, R.M. (1983) Free-living Marine Nematodes. Part I. British Enoplids. In: Kermack, D.M. \& Barnes, R.S.K. (Eds.), Synopses of British Fauna (New Series) n. 28, Cambridge University Press, Cambridge, pp. 307.

Riemann, F. (1966) Die interstitielle Fauna im Elbe-Aestuar. Verbreitung und Systematik, Archiv für Hydrobiologie, 31 (Supplement), 1-279.

Rho, H. \& Min, W. (2011) Nematoda: Chromadorea: Desmodorida: Draconematidae. Marine dragon nematodes. Invertebrate Fauna of Korea, 13, 1-100.

Ssaweljev, S. (1912) Zur Kenntnis der freilebenden Nematoden des Kolafjords und des Relictensee Mogilnoje. Travaux de la Société (Impériales) des Naturalistes de SaintPetersbourg, 43, 108-126.

Seinhorst, J. (1959) A rapid method for the transfer of nematodes from fixative to anhydrous glycerin. Nematologica, 4, 67-69. https://doi.org/10.1163/187529259X00381

Peer) reviewing PDF | (2019:06:38441:1:1:NEW 20 Sep 2019) 
773 Sergeeva, N.G. (1974) New Free-living Nematodes (Enoplida) from the Black Sea, Report 2

774

775

776

777

778

779

780

781

782

783

784

785

786

787

788

789

790

791

792

793

794

795

796

797

798

799

800 (Novye Vidy Svobodnozhivushchikh Nematod Otriada (Enoplida) iz Chernogo Moria, Soobshchenie 2). Zoologicheskii Zhurnal, 53 (1), 120-125.

Shipley, A.E. (1896) Nemathelminthes. In: Harmer, S.F. \& Shipley, A.E. (Eds) The Cambridge Natural History. Weldon \& Wesley, Cambridge, pp. 123-185.

Smol, N. \& Coomans, A. (2006) Order Enoplida. In: Eyualem, A., Traunspurger, W., Andrássy, A. (Eds), Freshwater Nematodes, Ecology and Taxonomy. CABI Publishing, Wallingford, Oxfordshire, pp. 225-292.

Smol, N., Muthumbi, A. \& Sharma, J. (2014) 7.3 Order Enoplida. In: Schmidt-Rhaesa, A. (Ed.), Handbook of zoology. Gastrotricha, Cycloneuralia, Gnathifera. Vol. 2. Nematoda. De Gruyter, Berlin, pp. 193-249.

Southern, R. (1914) Nemathelmia, Kinorhyncha and Cheatognatha (Clare Island survey, part 54). Proceedings of the Royal Irish Academy, 31, 1-80.

Timm, R.W. (1961) The marine nematodes of the Bay of Bengal. Proceedings of the Pakistan Academy of Sciences, 1 (1), 25-88.

Vitiello, P. (1971) Nématodes nouveaux des vases terrigènes cotières des côtes provençales. Téthys, 2, 859-876.

Warwick, R.M. (1970) Fourteen new species of marine nematodes from the Exe estuary. Bulletin of the British Museum (Natural History) Zoology, 19, 137-177.

Warwick, R.M. (1973) Freeliving marine nematodes from the Indian Ocean. Bulletin of the British Museum (Natural History) Zoology, 25 (3), 85-117.

Wieser, W. (1953) Reports of the Lund University Chile expedition 1948-49: 10. Free-living marine nematodes I. Enoploidea. Lunds Universitets Arsskrift 49 (6), 155 pp.

Wieser, W. (1959) Free-living nematodes and other small invertebrates of Puget Sound beaches. In: University of Washington Publications in Biology. Vol. 19. University of Washington Press, Seattle, pp. 1-179. 


\section{Tables}

802

803

804

Table 1. Measurement of diagnostic morphological characters of Mesacanthion jejuensis sp. nov. Measurements are in $\mu \mathrm{m}$ where applicable, and morphometric values rounded.

805

806

807

808

809

810

\section{Figures}

811

812

813

814

815

816

817

818

819

820

821

822

823

824

825

826

827

828

829

830

831

832

833

834

835

836

837

838

839

840

Figure 1. Map of sampling locality. This map is made with QGIS software v.2.18.14, a free and open source geographic information system.

Figure 2. Mesacanthion jejuensis sp. nov. male. A. head, lateral view; B. tail, with spicule and gubernaculum; C. total view; D. bipartite spicules with triangular gubernaculum. Scale bars: $20 \mu \mathrm{m}(\mathrm{A}, \mathrm{B}$, and D) and $200 \mu \mathrm{m}(\mathrm{C})$. Figure credit: Raehyuk Jeong.

Figure 3. Mesacanthion jejuensis sp. nov. female. A. head, lateral view; B. reproductive system with vulva protruding; C. total view; D. tail region with caudal glands; E. ventrosublateral mandible. Scale bars: $20 \mu \mathrm{m}$ (A and D), $100 \mu \mathrm{m}$ (B and C) and $10 \mu \mathrm{m}$ (E). Figure credit: Raehyuk Jeong.

Figure 4. Scanning electron micrograph of Mesacanthion jejuensis sp. nov. A. male, head region, lateral view, groups of cervical setae in doubles/trios with irregular lateral and terminal processes; B. male, head region showing contour of cephalic capsule end and triangular cervical setae flap just posterior to lateral outer labial seta; C. male, cloacal opening with distal end of gubernaculum peeking out; D. female, head region, lateral view, single cervical seta.

Figure 5. Mesacanthion jejuensis sp. nov. (A and B, paratype). A. lateral view of male cloacal region, showing a seam separating spicules in distal and proximal portions; B. lateral view of male cloacal region, showing distal end of spicule and triangular gubernaculum embracing the spicule. Scale bars: $30 \mu \mathrm{m}$ (A and B).

Figure 6. Pictorial key to species with spicules shorter than 2 anal body diameters within the genus Mesacanthion. A-D. species without supplementary organ with gubernaculum; EJ. species with supplementary organ without gubernaculum. Species with bipartite spicules marked with asterisk. Figure source: A. Warwick, 1970; B. Timm, 1961; C. Ditlevsen, 1930; D. Filipjev, 1927; E. Vitiello, 1971; F. Gerlach, 1967; G. Gerlach, 1967; H. Gerlach, 1957a; I. Gerlach, 1957a; J. Inglis, 1964.

Figure 7. Pictorial key to species with spicules shorter than 2 anal body diameters within the genus Mesacanthion. A-K. species with supplementary organ and gubernaculum. Species with bipartite spicules marked with asterisk. Figure source: A. Ditlevsen, 1918; B. Filipjev, 1927; C. Filipjev, 1927; D. Inglis, 1966; E. Mawson, 1958; F. Wieser, 1953; G. 
$841 \quad$ Filipjev, 1927; H. Wieser, 1953; I. Platonova \& Galtsova, 1976; J. Wieser, 1959; K. 842 Ditlevsen, 1930.

843 Figure 8. Pictorial key to species with spicules shorter than 2 anal body diameters within the 844 genus Mesacanthion. A-B. species with supplementary organ and gubernaculum along 845 with triangular cervical setae flaps. Species with bipartite spicules marked with asterisk. 
Figure 1

Map of sampling locality.

This map is made with QGIS software v.2.18.14, a free and open source geographic information system.

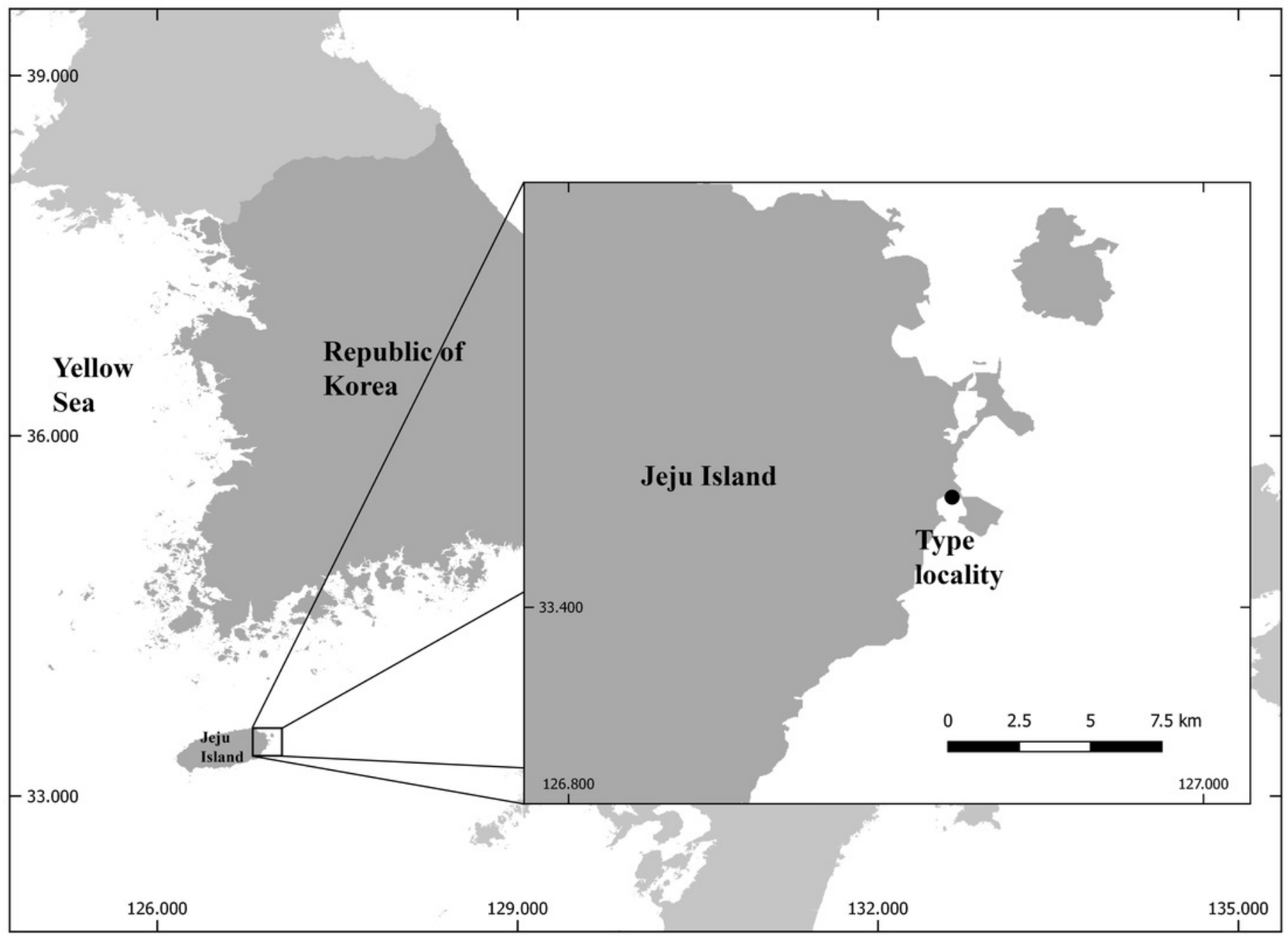


Figure 2

Mesacanthion jejuensis sp. nov. male.

(A) Head, lateral view. (B) Tail, with spicule and gubernaculum. (C) Total view. (D) Bipartite spicules with triangular gubernaculum. Scale bars: $20 \mu \mathrm{m}$ (A, B, and D) and $200 \mu \mathrm{m}$ (C). Figure credit: Raehyuk Jeong. 


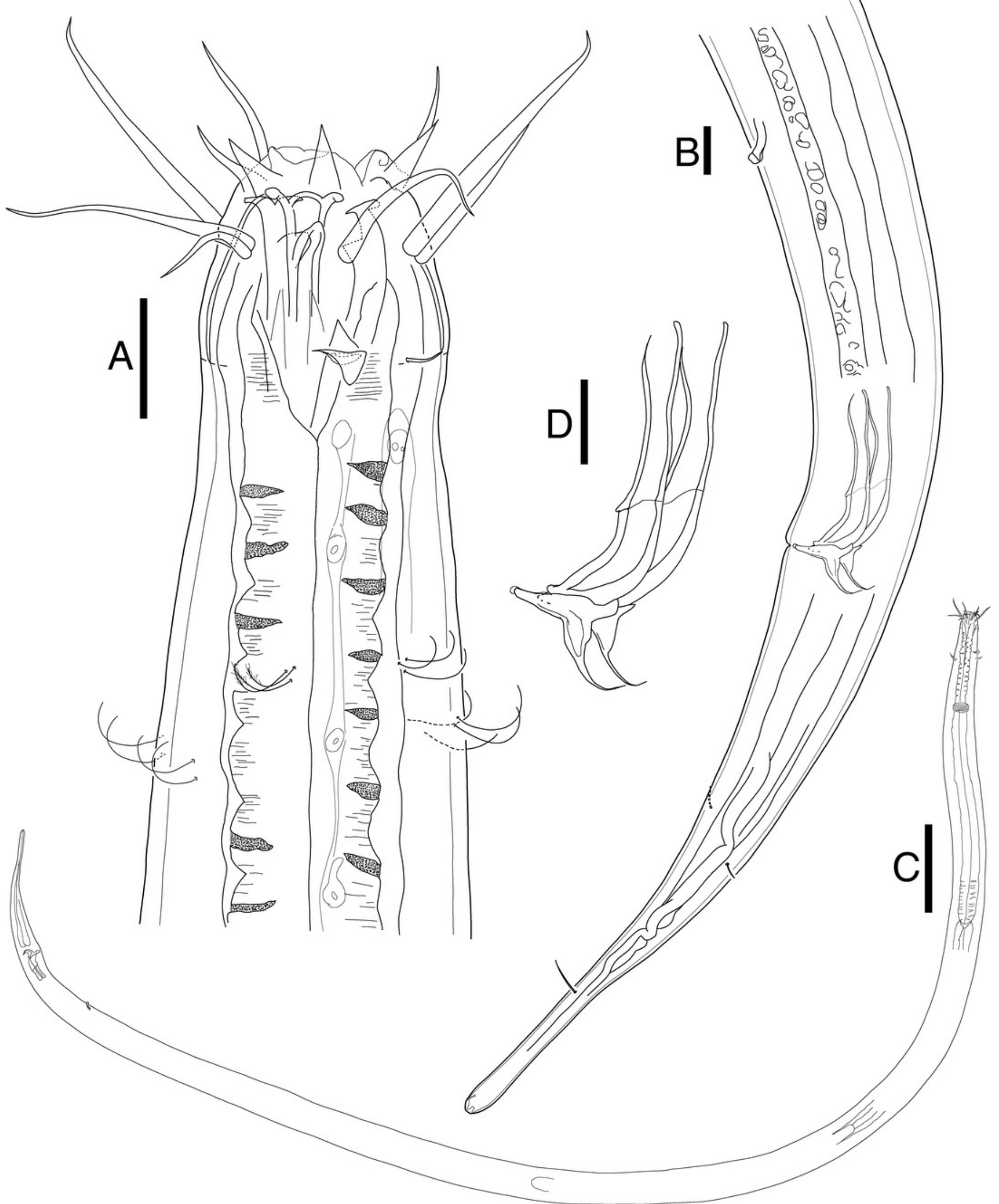


Figure 3

Mesacanthion jejuensis sp. nov. female.

(A) Head, lateral view. (B) Reproductive system with vulva protruding. (C) Total view. (D) tail region with caudal glands. (E) Ventrosublateral mandible. Scale bars: $20 \mu \mathrm{m}$ (A and D),100 $\mu \mathrm{m}(\mathrm{B}$ and $\mathrm{C}$ ) and $10 \mu \mathrm{m}(\mathrm{E})$. Figure credit: Raehyuk Jeong. 


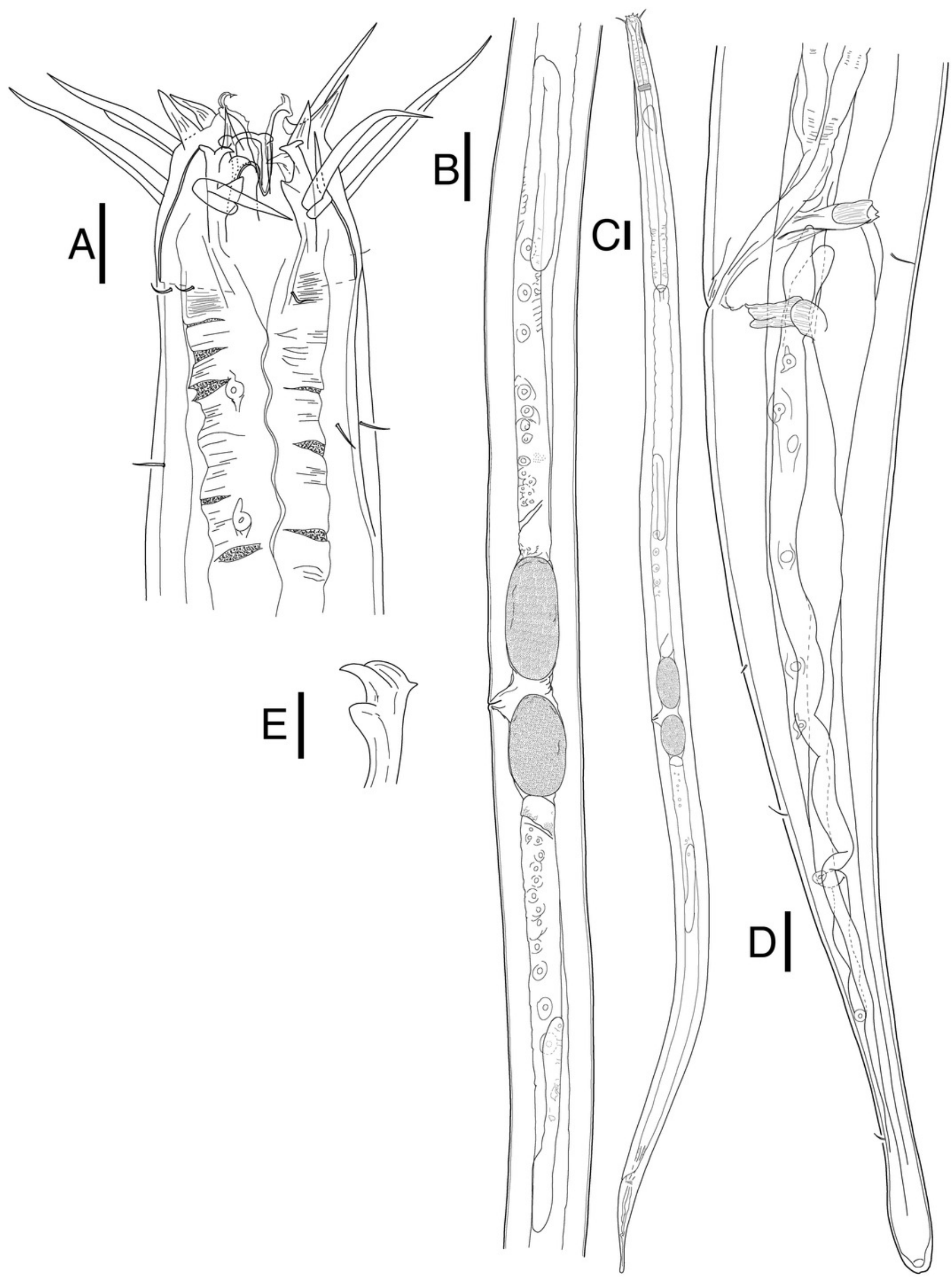




\section{Figure 4}

Scanning electron micrograph of Mesacanthion jejuensis sp. nov.

(A) Male, head region, lateral view, groups of cervical setae in doubles/trios with irregular lateral and terminal processes. (B) Male, head region showing contour of cephalic capsule end and triangular cervical setae flap just posterior to lateral outer labial seta. (C) Male, cloacal opening with distal end of gubernaculum peeking out. (D) Female, head region, lateral view, single cervical seta.

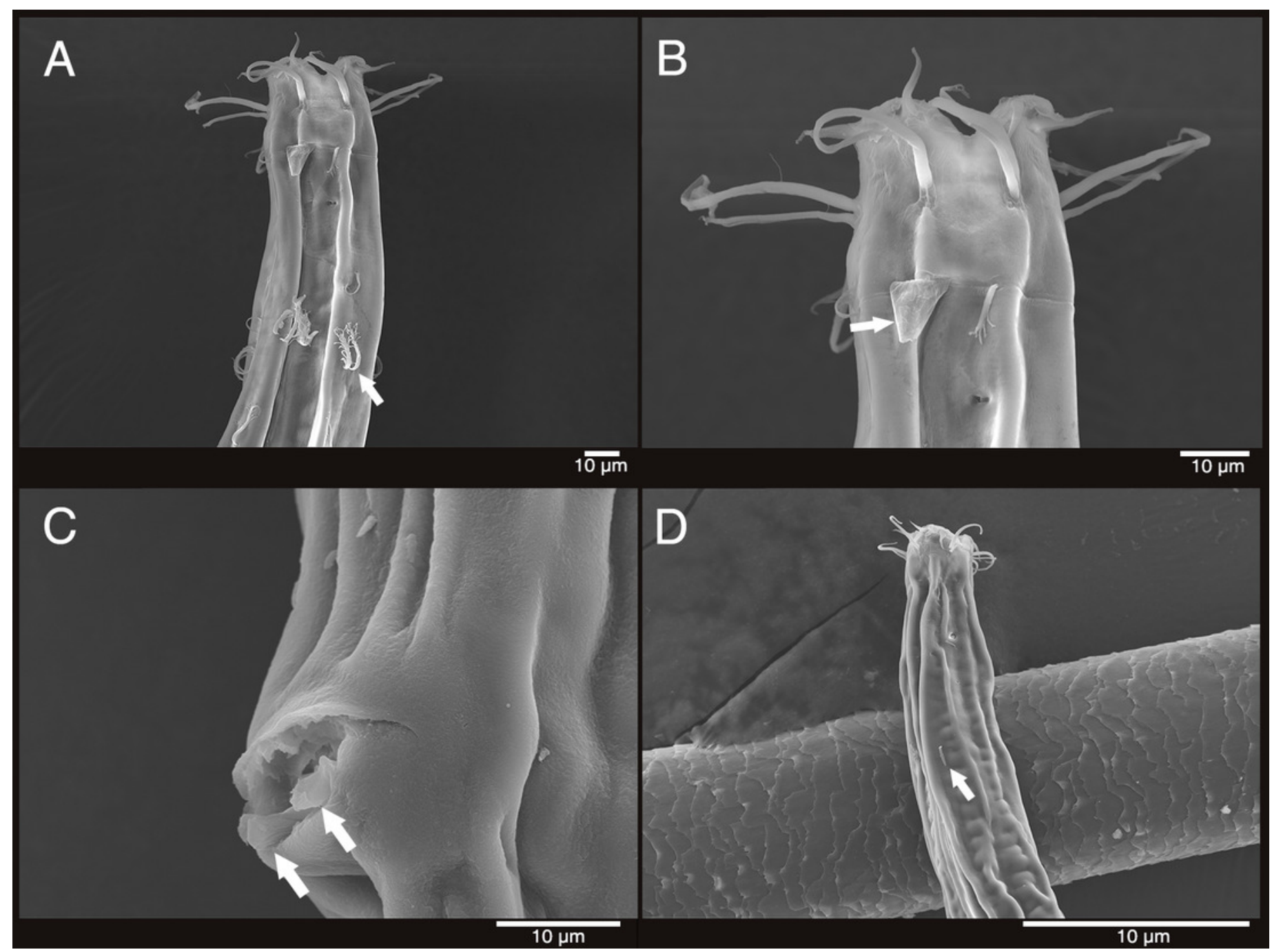




\section{Figure 5}

Mesacanthion jejuensis sp. nov. (A and B, paratype).

(A) Lateral view of male cloacal region, showing a seam separating spicules in distal and proximal portions. (B) Lateral view of male cloacal region, showing distal end of spicule and triangular gubernaculum. Scale bars: $30 \mu \mathrm{m}$ ( $\mathrm{A}$ and $\mathrm{B})$.

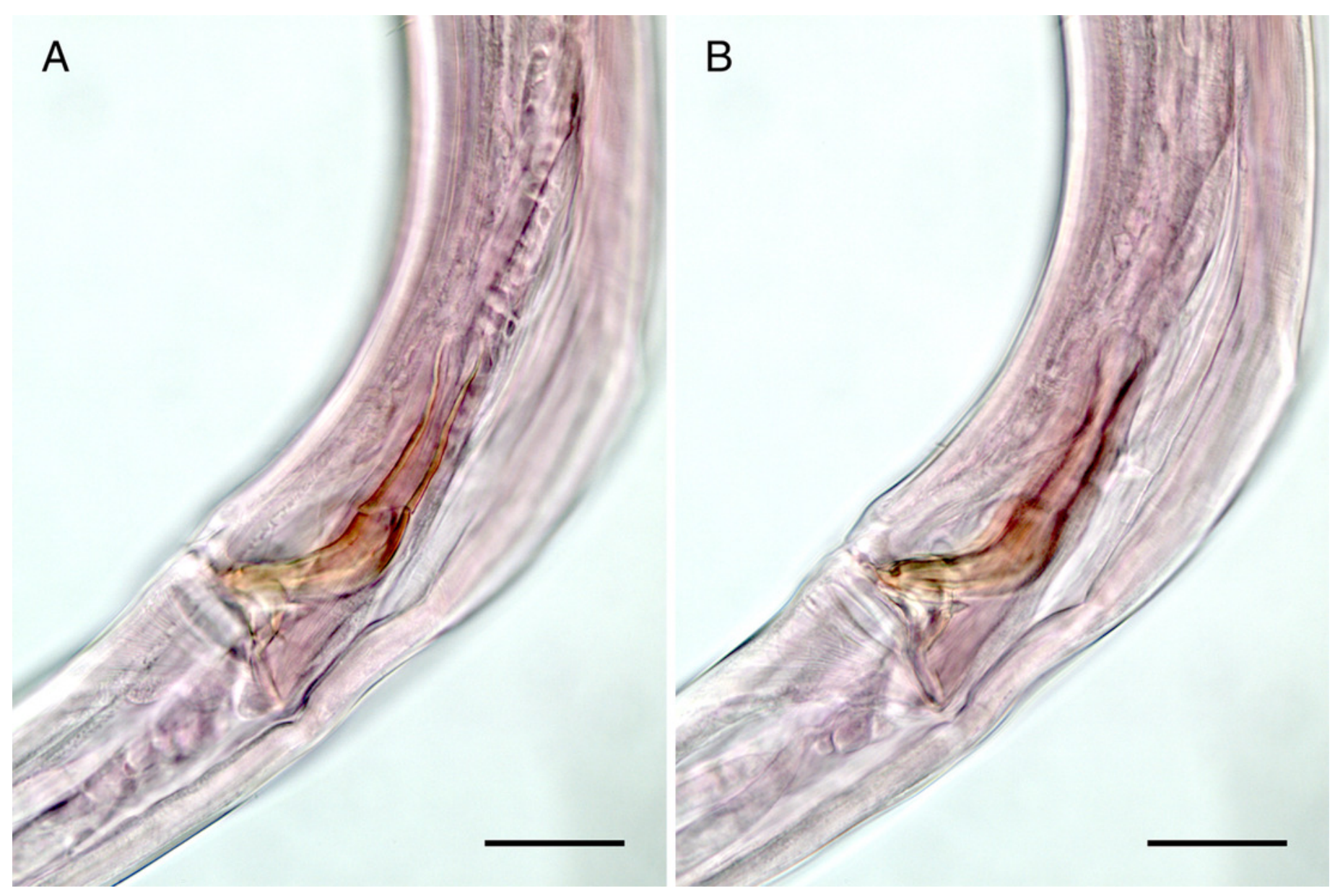




\section{Figure 6}

Pictorial key to species with spicules shorter than 2 anal body diameters within the genus Mesacanthion.

A-D. species without supplementary organ with gubernaculum; E-J. species with supplementary organ without gubernaculum. Species with bipartite spicules marked with asterisk. Figure source: (A) Warwick, 1970. (B) Timm, 1961. (C) Ditlevsen, 1930. (D) Filipjev, 1927. (E) Vitiello, 1971. (F) Gerlach, 1967. (G) Gerlach, 1967. (H) Gerlach, 1957a. (I) Gerlach, 1957a. (J) Inglis, 1964. 


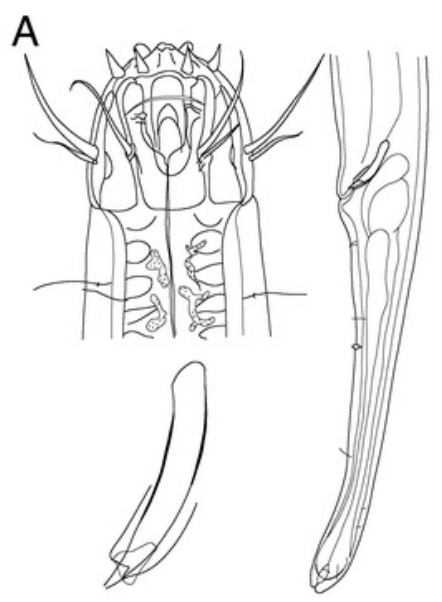

M. africanthiforme

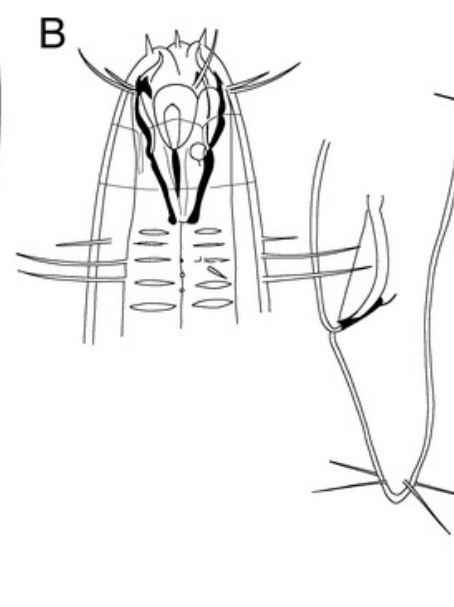

M. armatum
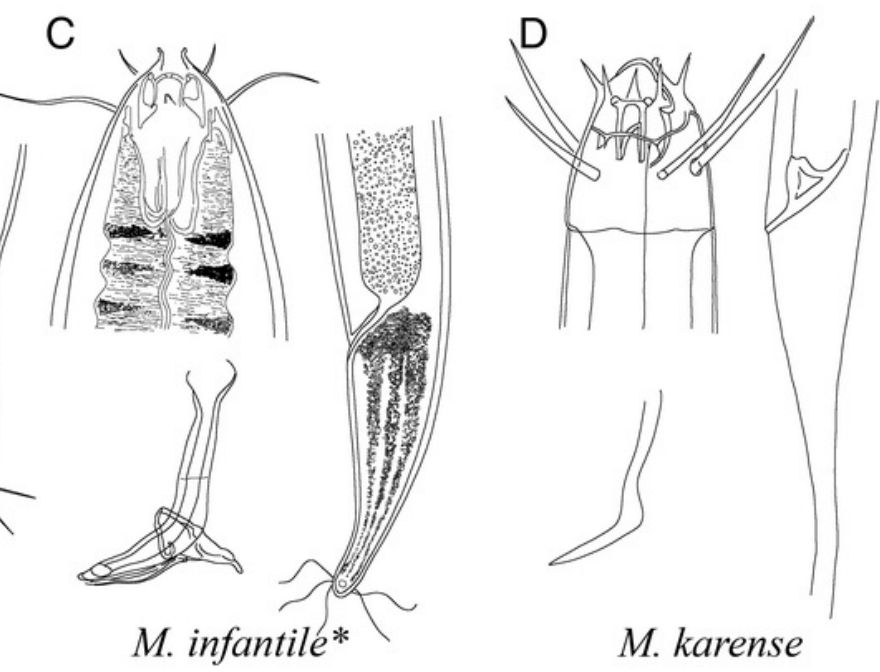

M. karense
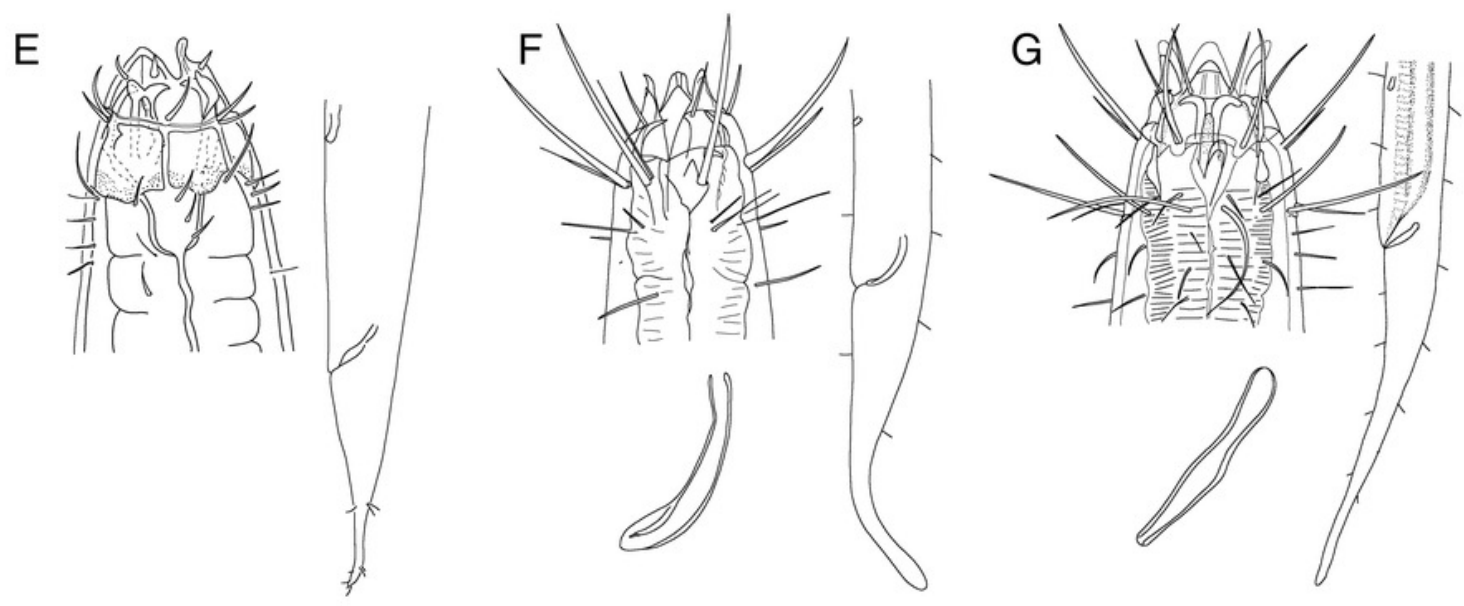

M. agubernatus

M. hirsutum

M. monhystera

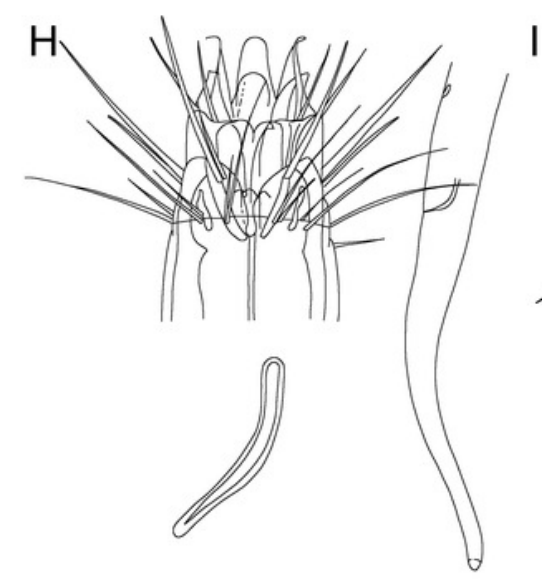

M. proximum

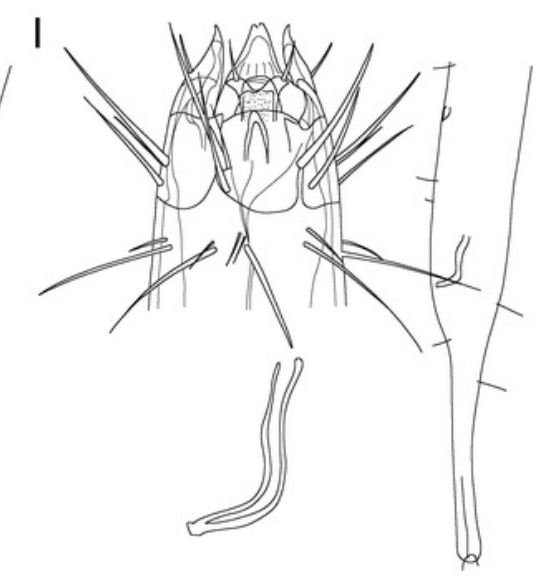

M. rigens

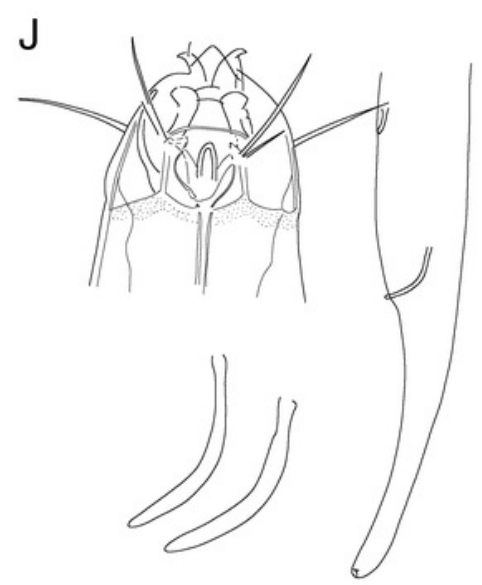

M. studiosum 


\section{Figure 7}

Pictorial key to species with spicules shorter than 2 anal body diameters within the genus Mesacanthion.

A-K. species with supplementary organ and gubernaculum. Species with bipartite spicules marked with asterisk. Figure source: (A) Ditlevsen, 1918. (B) Filipjev, 1927. (C) Filipjev, 1927. (D) Inglis, 1966. (E) Mawson, 1958. (F) Wieser, 1953. (G) Filipjev, 1927. (H) Wieser, 1953. (I) Platonova \& Galtsova, 1976. (J) Wieser, 1959. (K) Ditlevsen, 1930. 
A

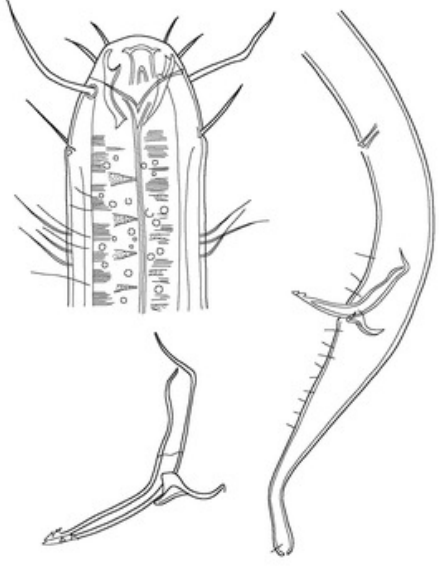

M. audax*

D

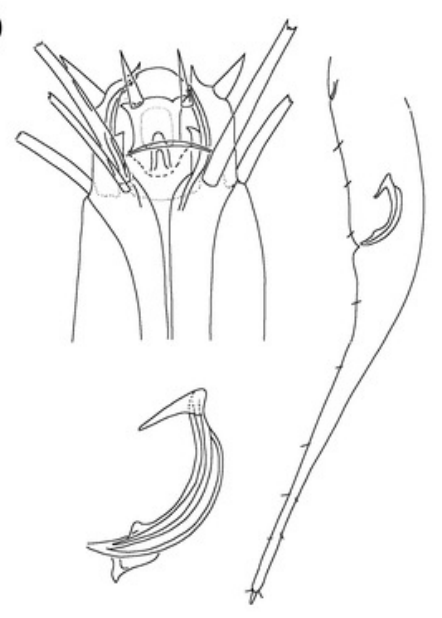

M. fricum
B

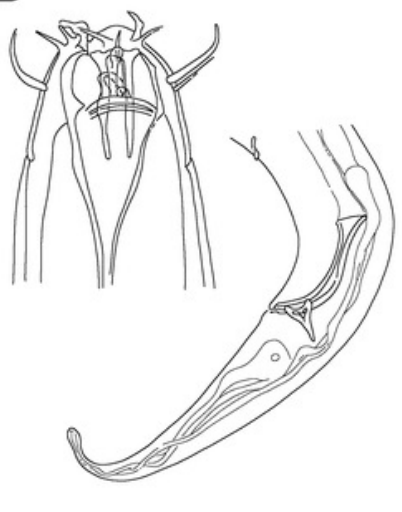

M. breviseta

C

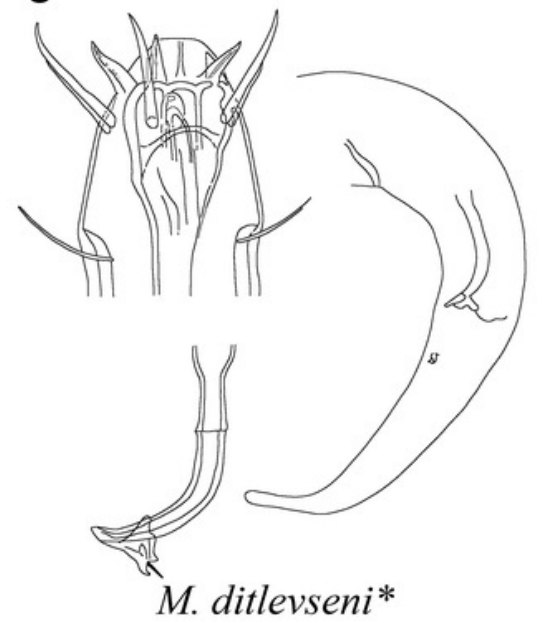

E
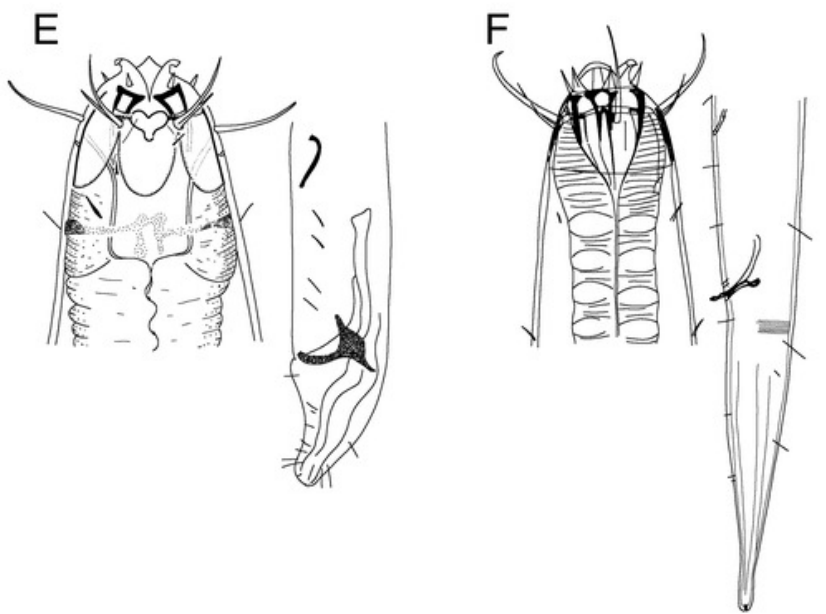

G

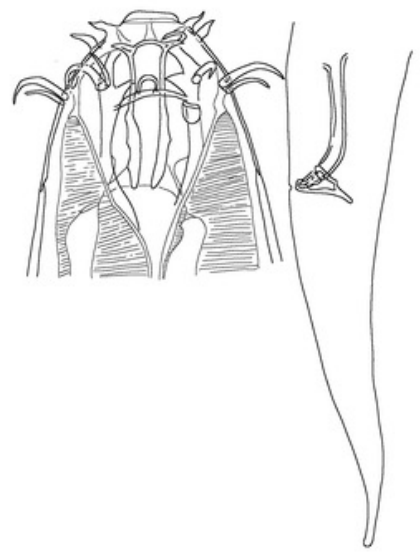

M. longissimesetosum

M. lucifer

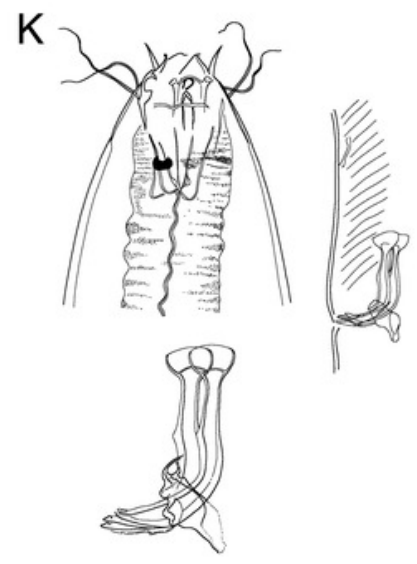

M. pali

M. virile 
Figure 8

Pictorial key to species with spicules shorter than 2 anal body diameters within the genus Mesacanthion.

A-B. species with supplementary organ and gubernaculum along with triangular cervical setae flaps. Species with bipartite spicules marked with asterisk. Figure source: (A) Wieser, 1959. Figure credit: (B) Raehyuk Jeong.

A

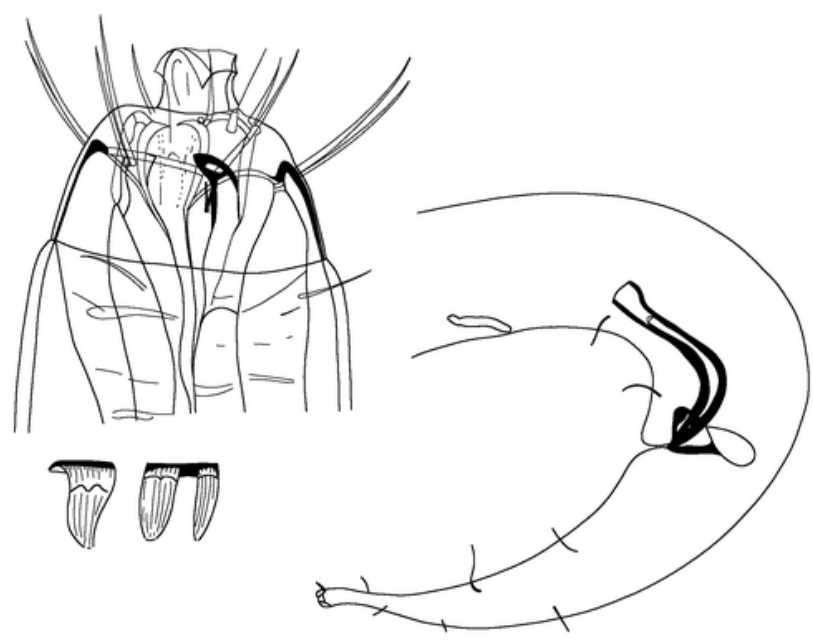

M. pannosum
B

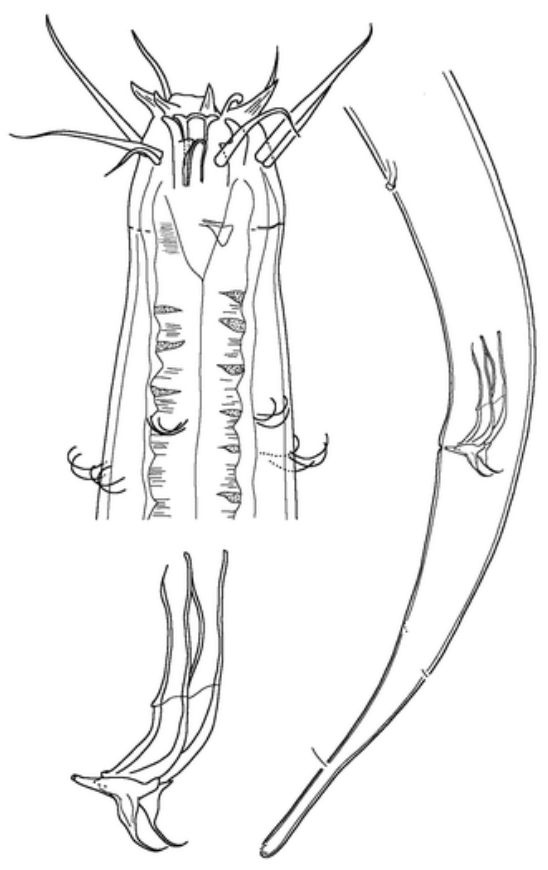

M. jejuensis sp. nov. * 


\section{Table $\mathbf{1}$ (on next page)}

Measurement of diagnostic morphological characters of Mesacanthion jejuensis sp. nov.

Measurements are in $\mu m$ where applicable, and morphometric values rounded. 


\begin{tabular}{|c|c|c|c|}
\hline Characters & $\begin{array}{c}\text { ๙ } \\
\text { holotype }\end{array}$ & $\begin{array}{c}\delta(n=4) \\
\text { mean } \pm \text { sd (range) }\end{array}$ & $\begin{array}{c}\bigcirc(\mathbf{n}=3) \\
\text { mean } \pm \text { sd (range) }\end{array}$ \\
\hline body length & 3682 & $3401 \pm 476(2703-3723)$ & $3719 \pm 808(3080-4627)$ \\
\hline maximum body diameter & 79 & $79 \pm 3(76-82)$ & $108 \pm 31(80-141)$ \\
\hline diameter at the level of cephalic setae & 39 & $36 \pm 3(32-39)$ & $38 \pm 7(34-46)$ \\
\hline length of inner labial setae & 12 & $13 \pm 2(11-15)$ & $12 \pm 1(11-13)$ \\
\hline length of outer labial setae & 43 & $51 \pm 7(43-59)$ & $41 \pm 5(38-47)$ \\
\hline length of cephalic setae & 28 & $28 \pm 7(18-34)$ & $25 \pm 1(24-26)$ \\
\hline distance from anterior to cephalic setae & 19 & $15 \pm 4(11-19)$ & $16 \pm 4(13-21)$ \\
\hline width at cephalic capsule end & 42 & $43 \pm 2(41-45)$ & $45 \pm 7(40-53)$ \\
\hline length of cephalic capsule & 29 & $28 \pm 2(25-30)$ & $30 \pm 5(26-36)$ \\
\hline buccal cavity length & 50 & $44 \pm 5(37-50)$ & $44 \pm 6(38-49)$ \\
\hline distance from nerve ring from anterior end & 212 & $202 \pm 28(161-220)$ & $204 \pm 9(194-209)$ \\
\hline pharynx (oesophagus) length & 731 & $706 \pm 74(598-764)$ & $706 \pm 16(687-715)$ \\
\hline corresponding body diameter at pharynx & 76 & $76 \pm 2(74-78)$ & $97 \pm 23(76-122)$ \\
\hline cardia length & 21 & $23 \pm 2(21-25)$ & $23 \pm 4(18-26)$ \\
\hline tail length & 287 & $275 \pm 44(209-304)$ & $286 \pm 48(257-342)$ \\
\hline anal body diameter & 50 & $54 \pm 4(50-60)$ & $58 \pm 12(48-71)$ \\
\hline$c^{\prime}$ & 5.7 & $5.1 \pm 0.8(4-5.7)$ & $4.9 \pm 0.4(4.6-5.4)$ \\
\hline length of conical tail & 223.0 & $209 \pm 35(157-229)$ & $227 \pm 40(203-273)$ \\
\hline length of cylindrical tail & 64 & $66 \pm 11(52-78)$ & $59 \pm 9(52-69)$ \\
\hline $\begin{array}{l}\text { cylindrical tail length portion as percentage of tail } \\
\text { length }\end{array}$ & 0 & $0.3 \pm 0(0.3-0.3)$ & $0.3 \pm 0(0.3-0.3)$ \\
\hline spicule length as arc & 76 & $79 \pm 6(72-85)$ & $\mathrm{n} / \mathrm{a}$ \\
\hline spicule length as arc / anal body diameter & 1.5 & $1.5 \pm 0.1(1.4-1.6)$ & $\mathrm{n} / \mathrm{a}$ \\
\hline length of gubernaculum & 50 & $45 \pm 5(39-50)$ & $\mathrm{n} / \mathrm{a}$ \\
\hline supplementary organ length & 18 & $15 \pm 3(10-18)$ & $\mathrm{n} / \mathrm{a}$ \\
\hline $\begin{array}{l}\text { distance from cloacal opening to supplementary } \\
\text { organ }\end{array}$ & 165 & $160 \pm 16(136-171)$ & $\mathrm{n} / \mathrm{a}$ \\
\hline distance from anterior end to vulva & $\mathrm{n} / \mathrm{a}$ & $\mathrm{n} / \mathrm{a}$ & $2027 \pm 459(1685-2549)$ \\
\hline corresponding body diameter at vulva & $\mathrm{n} / \mathrm{a}$ & $\mathrm{n} / \mathrm{a}$ & $108 \pm 31(80-141)$ \\
\hline $\begin{array}{l}\text { distance from anterior end to vulva as percentage of } \\
\text { total body length }\end{array}$ & $\mathrm{n} / \mathrm{a}$ & $\mathrm{n} / \mathrm{a}$ & $54 \pm 1(54-55)$ \\
\hline $\mathrm{a}$ & 46.6 & $43.1 \pm 5.1(35.6-46.6)$ & $34.9 \pm 3.1(32.8-38.5)$ \\
\hline $\mathrm{b}$ & 5 & $4.8 \pm 0.2(4.5-5)$ & $4.6 \pm 0.2(4.5-4.8)$ \\
\hline $\mathrm{c}$ & 12.8 & $12.4 \pm 0.6(11.7-12.9)$ & $12.9 \pm 0.8(12-13.5)$ \\
\hline
\end{tabular}

1

2 Table 1. Measurement of major morphological characters of Mesacanthion jejuensis sp. nov. 3 Measurements are in $\mu \mathrm{m}$ where applicable, and morphometric values rounded. 


\section{Table 2 (on next page)}

Comparison of diagnostic morphological characters of all Mesacanthion species.

Species with spicules shorter than 2 anal body diameters marked with asterisk. Males only, morphometric values rounded. 


\begin{tabular}{|c|c|c|c|c|c|c|c|c|c|c|c|}
\hline \multirow[b]{2}{*}{ Species } & \multirow{2}{*}{$\begin{array}{c}\text { Body } \\
\text { length } \\
{[\mu \mathrm{m}]}\end{array}$} & \multirow[b]{2}{*}{ a } & \multirow[b]{2}{*}{ b } & \multirow[b]{2}{*}{ c } & \multirow[b]{2}{*}{$\mathbf{c}^{\prime}$} & \multicolumn{2}{|c|}{ Length of Setae } & \multirow{2}{*}{$\begin{array}{c}\text { Spicule } \\
\text { length }[\mu \mathrm{m}] \\
\text { (spicule } \\
\text { length as } \\
\text { arc/abd) } \\
\text { left/right if } \\
\text { applicable } \\
\end{array}$} & \multirow[b]{2}{*}{ Spicule type } & \multirow[b]{2}{*}{$\begin{array}{l}\text { Gubernaculum } \\
\text { (length }[\mu \mathrm{m}] \text { ) }\end{array}$} & \multirow{2}{*}{ 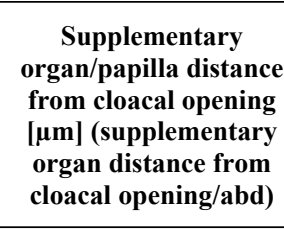 } \\
\hline & & & & & & $\begin{array}{l}\text { Inner } \\
\text { labial } \\
\text { Setae }\end{array}$ & $\begin{array}{l}\text { Outer labial } \\
\text { setae/cephali } \\
\text { c setae }\end{array}$ & & & & \\
\hline $\begin{array}{l}\text { Mesacanthion } \\
\text { africanthiforme Warwick, } \\
\text { 1970* }\end{array}$ & $\begin{array}{l}2370- \\
4490\end{array}$ & $\begin{array}{l}65.8- \\
81.8\end{array}$ & $\begin{array}{l}4.1- \\
5.4\end{array}$ & $\begin{array}{l}16- \\
19.6\end{array}$ & $\begin{array}{l}4.5-4.9 \\
\text { calc }\end{array}$ & $6-8$ & $24-41 / 10-20$ & $\begin{array}{l}20-33(0.6- \\
0.7 \text { calc })\end{array}$ & $\begin{array}{l}\text { symmetrical/unipa } \\
\text { rtite }\end{array}$ & present $(10-13)$ & absent \\
\hline $\begin{array}{l}\text { Mesacanthion africanum } \\
\text { Gerlach, } 1957\end{array}$ & 3345 & 33 & 6.1 & 12.6 & 3.7 & 6.5 & 15 & $\begin{array}{l}85 / 180 \\
(1.2 / 2.5 \text { calc })\end{array}$ & $\begin{array}{l}\text { asymmetrical/bipa } \\
\text { rtite/striated }\end{array}$ & present $(53 / 44)$ & present (88) \\
\hline $\begin{array}{l}\text { Mesacanthion agubernatus } \\
\text { Vitiello, 1971* }\end{array}$ & 3120 & 34.6 & 3.7 & 21.5 & 3.2 & 8 & $14-19$ & $41(0.9)$ & $\begin{array}{l}\text { symmetrical/unipa } \\
\text { rtite }\end{array}$ & absent & present (155) \\
\hline $\begin{array}{l}\text { Mesacanthion } \\
\text { alexandrinus Nicholas, } \\
1993\end{array}$ & $\begin{array}{l}1450- \\
2460\end{array}$ & $33-43$ & $\begin{array}{l}3.1- \\
3.6\end{array}$ & $\begin{array}{l}14- \\
22\end{array}$ & $3.4-4.5$ & $12-13$ & $27-29 / 12-16$ & $\begin{array}{l}79-86(2.5- \\
3.6)\end{array}$ & $\begin{array}{l}\text { asymmetrical/unip } \\
\text { artite }\end{array}$ & $\begin{array}{l}\text { present (not } \\
\text { measured) }\end{array}$ & present (64-70) \\
\hline $\begin{array}{l}\text { Mesacanthion arabium } \\
\text { Warwick, } 1973\end{array}$ & $\begin{array}{l}5780- \\
6250\end{array}$ & $\begin{array}{l}30.4- \\
37.0\end{array}$ & $\begin{array}{l}4.8- \\
5.2\end{array}$ & $\begin{array}{l}16.1 \\
- \\
18.4\end{array}$ & $\begin{array}{l}3.7-3.9 \\
\text { calc }\end{array}$ & $23-25$ & $56-65 / 27-32$ & $\begin{array}{l}570-610 \\
(6.2-6.8 \text { calc })\end{array}$ & $\begin{array}{l}\text { unclear/unipartite/ } \\
\text { striated }\end{array}$ & $\begin{array}{l}\text { present }(120- \\
127)\end{array}$ & present $(220-230)$ \\
\hline $\begin{array}{l}\text { Mesacanthion arcuatile } \\
\text { Wieser, } 1959\end{array}$ & \multicolumn{11}{|c|}{ no male described or measured } \\
\hline $\begin{array}{l}\text { Mesacanthion armatum } \\
\text { Timm, 1961* }\end{array}$ & $\begin{array}{l}1630- \\
1940\end{array}$ & $\begin{array}{l}23- \\
51.1\end{array}$ & $\begin{array}{l}4.5- \\
5.7\end{array}$ & $\begin{array}{l}43.2 \\
-51\end{array}$ & $1.5-2$ & 5 & $14 / 9$ & 41 (1.4 calc) & $\begin{array}{l}\text { symmetrical/unipa } \\
\text { rtite }\end{array}$ & $\begin{array}{l}\text { present (not } \\
\text { measured) }\end{array}$ & absent \\
\hline $\begin{array}{l}\text { Mesacanthion audax } \\
\text { (Ditlevsen, 1918) Filipjev, } \\
\text { 1927* }\end{array}$ & 3700 & 57 & 4.8 & 14.5 & 3.2 & $\begin{array}{l}\text { not } \\
\text { measured }\end{array}$ & not measured & 143 calc $(1.8)$ & $\begin{array}{l}\text { symmetrical/bipar } \\
\text { tite }\end{array}$ & $\begin{array}{l}\text { present (not } \\
\text { measured) }\end{array}$ & present (178) \\
\hline
\end{tabular}


Mesacanthion banale

(Filipjev, 1927) Gerlach \&

Riemann, 1974

Mesacanthion brachycolle Allgén, 1959

Mesacanthion breviseta

(Filipjev, 1927) Gerlach \&

Riemann, 1974*

Mesacanthion cavei Inglis,

1964

Mesacanthion ceeum

Inglis, 1964

Mesacanthion conicum

(Filipjev, 1918) Filipjev,

1927

Mesacanthion cricetoides Wieser, 1959

Mesacanthion diplechma (Southern, 1914) Filipjev, 1927

Mesacanthion ditlevseni (Filipjev, 1927) Gerlach \& Riemann, 1974*

Mesacanthion fricum Inglis, 1966* no male described or measured

no male described or measured

3960

23

4

123 calc

10

$20 / 15$

$165(1.5)$

symmetrical/unipa

rtite

present (60)

absent

4200

38.2

4.2

$17.5 \quad 3.75$

13

$59 / 35$

$510(8.0$ calc $) \quad$ symmetrical/unipa

present (38)

present (161)

not

measured

/mention

59

430 (9.0 calc) $\quad$ symmetrical/unipa

present (31)

present (121)

no male described or measured

no male described or measured

\begin{tabular}{|c|c|c|c|c|c|c|c|c|c|c|}
\hline $\begin{array}{l}3330- \\
3980\end{array}$ & $\begin{array}{l}39.8- \\
43.8\end{array}$ & $\begin{array}{l}5.4- \\
5.9\end{array}$ & $\begin{array}{l}12.6 \\
- \\
14.8\end{array}$ & $\begin{array}{l}4.0-4.6 \\
\text { calc }\end{array}$ & 11 & $45-/ 35-$ & $\begin{array}{l}95(1.2 \\
\text { calc }) / 500-598 \\
(7.8 \text { calc })\end{array}$ & $\begin{array}{l}\text { asymmetrical/bipa } \\
\text { rtite/striated }\end{array}$ & $\begin{array}{l}\text { present (not } \\
\text { measured) }\end{array}$ & present $(80)$ \\
\hline $\begin{array}{l}3580- \\
6250\end{array}$ & $\begin{array}{l}31.2- \\
38\end{array}$ & $\begin{array}{l}4.3- \\
5.7\end{array}$ & $\begin{array}{l}14- \\
17.9\end{array}$ & $\begin{array}{l}3.4- \\
4.8 \\
\text { calc }\end{array}$ & $12-16$ & $\begin{array}{l}21-26 / \text { not } \\
\text { measured }\end{array}$ & $\begin{array}{l}87-100(1.4- \\
1.8)\end{array}$ & $\begin{array}{l}\text { symmetrical/bipar } \\
\text { tite }\end{array}$ & present (43-47) & present $(155-172$ calc $)$ \\
\hline 1650 & 42.3 & 3.75 & $\begin{array}{l}9.07 \\
\text { calc }\end{array}$ & 5.05 & 13 & $96 / 51$ & $40(1.1 \mathrm{calc})$ & $\begin{array}{l}\text { symmetrical/unipa } \\
\text { rtite }\end{array}$ & $\begin{array}{l}\text { small/"uncertain } \\
\text { " }\end{array}$ & present (78) \\
\hline
\end{tabular}




\begin{tabular}{|c|c|c|c|c|c|c|c|c|c|c|c|}
\hline $\begin{array}{l}\text { Mesacanthion } \\
\text { heterospiculum Sergeeva, } \\
1974\end{array}$ & $\begin{array}{l}2394- \\
2398\end{array}$ & $\begin{array}{l}23.7- \\
23.9\end{array}$ & $\begin{array}{l}4.4- \\
4.6\end{array}$ & $\begin{array}{l}13.6 \\
- \\
14.2\end{array}$ & $\begin{array}{l}\text { not } \\
\text { measur } \\
\text { ed }\end{array}$ & 6.2 & not measured & 109/54 (2/1) & $\begin{array}{l}\text { asymmetrical/stria } \\
\text { ted }\end{array}$ & present (19) & present (35) \\
\hline $\begin{array}{l}\text { Mesacanthion hirsutum } \\
\text { Gerlach, 1953* }\end{array}$ & $\begin{array}{l}1155- \\
1532\end{array}$ & $40-49$ & $\begin{array}{l}3.4- \\
3.9\end{array}$ & $9-12$ & $\begin{array}{l}4.3-6.1 \\
\text { calc }\end{array}$ & $8-14$ & $22-24 / 14$ & 21-33 (1.3) & $\begin{array}{l}\text { symmetrical/unipa } \\
\text { rtite }\end{array}$ & absent & present $(45-100)$ \\
\hline $\begin{array}{l}\text { Mesacanthion infantile } \\
\text { (Ditlevsen, 1930) De } \\
\text { Coninck \& Schuurmans } \\
\text { Stekhoven, 1933* }\end{array}$ & $\begin{array}{l}3230- \\
5400\end{array}$ & $\begin{array}{l}23.7- \\
24.8\end{array}$ & $\begin{array}{l}4- \\
4.7\end{array}$ & $\begin{array}{l}14.0 \\
-19\end{array}$ & $2.5-3$ & $10-15$ & $\begin{array}{l}36-54 \\
\text { calc/ } / 20-35\end{array}$ & $\begin{array}{l}112 \text { calc (abd } \\
\text { not given or } \\
\text { depicted) }\end{array}$ & $\begin{array}{l}\text { symmetrical/bipar } \\
\text { tite }\end{array}$ & $\begin{array}{l}\text { present (not } \\
\text { measured) }\end{array}$ & absent \\
\hline $\begin{array}{l}\text { Mesacanthion karense } \\
\text { (Filipjev, 1927) Gerlach \& } \\
\text { Riemann, 1974* }\end{array}$ & 1750 & $35-39$ & $\begin{array}{l}4.5- \\
4.9\end{array}$ & $\begin{array}{l}12- \\
16\end{array}$ & $4.1-6$ & 10 & $33-36 / 24-26$ & $24(1)$ & $\begin{array}{l}\text { symmetrical/unipa } \\
\text { rtite }\end{array}$ & present (14) & $\begin{array}{l}\text { not described, not } \\
\text { depicted }\end{array}$ \\
\hline $\begin{array}{l}\text { Mesacanthion kerguelense } \\
\text { Mawson, } 1958^{*}\end{array}$ & $\begin{array}{l}3500- \\
9000\end{array}$ & $\begin{array}{l}20.5- \\
40\end{array}$ & $\begin{array}{l}3.5- \\
5.7\end{array}$ & $\begin{array}{l}25- \\
26\end{array}$ & $1.3-1.5$ & 8 & $40-50 / 25-30$ & $\begin{array}{l}150-200(1.9 \\
\text { calc) }\end{array}$ & $\begin{array}{l}\text { symmetrical/unipa } \\
\text { rtite(with tapering } \\
\text { point) }\end{array}$ & $\begin{array}{l}\text { present (not } \\
\text { measured) }\end{array}$ & $\begin{array}{l}\text { present (proximal end of } \\
\text { spicule) }\end{array}$ \\
\hline $\begin{array}{l}\text { Mesacanthion } \\
\text { longispiculum Gerlach, } \\
1954\end{array}$ & $\begin{array}{l}2228- \\
2575\end{array}$ & $49-55$ & $\begin{array}{l}3- \\
3.3\end{array}$ & $\begin{array}{l}18- \\
25.8\end{array}$ & $2.7-3.8$ & $11-17$ & $33-38 / 13-16$ & $\begin{array}{l}75-143(3.0- \\
4.0 \text { calc) }\end{array}$ & $\begin{array}{l}\text { symmetrical/unipa } \\
\text { rtite }\end{array}$ & $\begin{array}{l}\text { not described, } \\
\text { not depicted }\end{array}$ & present $(87-90)$ \\
\hline $\begin{array}{l}\text { Mesacanthion } \\
\text { longissimesetosum Wieser, } \\
\text { 1953* }\end{array}$ & $\begin{array}{l}3260- \\
4270\end{array}$ & $\begin{array}{l}29.2- \\
31.7\end{array}$ & $\begin{array}{l}5.1- \\
5.3\end{array}$ & $\begin{array}{l}11.1 \\
- \\
13.2\end{array}$ & $4.2-4.5$ & 12 & $65-70 / 40$ & $83(1.1)$ & $\begin{array}{l}\text { symmetrical/unipa } \\
\text { rtite }\end{array}$ & present (39) & present (166) \\
\hline $\begin{array}{l}\text { Mesacanthion lucifer } \\
\text { (Filipjev, 1927) Gerlach \& } \\
\text { Riemann, 1974* }\end{array}$ & 4390 & $26-30$ & $\begin{array}{l}4.3- \\
4.6\end{array}$ & 10.7 & $\begin{array}{l}4.1 \\
\text { (calc) }\end{array}$ & 10 & $22-23$ & $155(1.5)$ & $\begin{array}{l}\text { symmetrical/unipa } \\
\text { rtite }\end{array}$ & present (55) & present $(\sim 300)$ \\
\hline $\begin{array}{l}\text { Mesacanthion majus } \\
\text { (Filipjev, 1927) Gerlach \& } \\
\text { Riemann, 1974* }\end{array}$ & $\begin{array}{l}2840- \\
3170\end{array}$ & $\begin{array}{l}26.0- \\
33.9\end{array}$ & $\begin{array}{l}4.2- \\
4.9\end{array}$ & $\begin{array}{l}11.7 \\
- \\
12.8\end{array}$ & $4-4.3$ & $11.5-12$ & $40 / 26$ & $80(1.35)$ & $\begin{array}{l}\text { symmetrical/unipa } \\
\text { rtite }\end{array}$ & present (27) & present (134) \\
\hline $\begin{array}{l}\text { Mesacanthion marisalbi } \\
\text { Platonova, 1976* }\end{array}$ & $\begin{array}{l}2992- \\
4037\end{array}$ & $\begin{array}{l}45.4- \\
52.4\end{array}$ & $\begin{array}{l}4.3- \\
5.5\end{array}$ & $\begin{array}{l}16- \\
20.1\end{array}$ & $\begin{array}{l}4.4-4.6 \\
\text { (calc) }\end{array}$ & $6-8$ & $\begin{array}{l}\text { not } \\
\text { measured/61. } \\
2-64.0\end{array}$ & $\begin{array}{l}56.7(1.4 \\
\text { calc) }\end{array}$ & $\begin{array}{l}\text { symmetrical/unipa } \\
\text { rtite }\end{array}$ & present (21.6) & present (126.9) \\
\hline
\end{tabular}




\begin{tabular}{|c|c|c|c|c|c|c|c|c|c|c|c|}
\hline $\begin{array}{l}\text { Mesacanthion monhystera } \\
\text { Gerlach, } 1967^{*}\end{array}$ & 1833 & 48 & 3 & 9.6 & $\begin{array}{l}6.3 \\
\text { calc }\end{array}$ & $12-13$ & $23-25 / 9-10$ & $25(0.8$ calc $)$ & $\begin{array}{l}\text { symmetrical/unipa } \\
\text { rtite }\end{array}$ & absent & present (85) \\
\hline $\begin{array}{l}\text { Mesacanthion obscurum } \\
\text { Gagarin \& Klerman, } 2006\end{array}$ & $\begin{array}{l}2163- \\
3148\end{array}$ & $19-32$ & $\begin{array}{l}3.5- \\
5.2\end{array}$ & $\begin{array}{l}12.4 \\
- \\
18.1\end{array}$ & $3.0-4.2$ & $7-10$ & $37-43 / 23-27$ & $\begin{array}{l}70-81 / 269- \\
310(1.4 / 5.2 \\
\text { calc) }\end{array}$ & $\begin{array}{l}\text { asymmetrical/bipa } \\
\text { rtite/striated }\end{array}$ & present (28-35) & present (36-59) \\
\hline $\begin{array}{l}\text { Mesacanthion pali Wieser, } \\
\text { 1959* }\end{array}$ & 2160 & 54 & 3.3 & 15.4 & 2.8 & 24 & $84 / 8$ & $62(1.3$ calc $)$ & $\begin{array}{l}\text { symmetrical/unipa } \\
\text { rtite }\end{array}$ & present (26) & present (78) \\
\hline $\begin{array}{l}\text { Mesacanthion pannosum } \\
\text { Wieser, 1959* }\end{array}$ & 4100 & 41 & 6.3 & 13.7 & 3 & $11-12$ & $24-25 / 22$ & 135 ( 1.5 calc $)$ & $\begin{array}{l}\text { symmetrical/unipa } \\
\text { rtite }\end{array}$ & present (66) & present (180) \\
\hline $\begin{array}{l}\text { Mesacanthion propinquum } \\
\text { Gagarin \& Klerman, } 2006\end{array}$ & $\begin{array}{l}2076- \\
2674\end{array}$ & $19-30$ & $\begin{array}{l}4.0- \\
5.1\end{array}$ & $\begin{array}{l}10.8 \\
- \\
15.8\end{array}$ & $2.7-4.5$ & $4.0-4.5$ & $\begin{array}{l}11-15 / 7.0- \\
8.5\end{array}$ & $\begin{array}{l}70-77 / 239- \\
308(1.2 / 4.2 \\
\text { calc) }\end{array}$ & $\begin{array}{l}\text { asymmetrical/bipa } \\
\text { rtite }\end{array}$ & present $(26-30)$ & present (28-31) \\
\hline $\begin{array}{l}\text { Mesacanthion proximum } \\
\text { Gerlach, } 1957^{*}\end{array}$ & 1340 & 54 & 3.1 & 9.6 & $7-8$ & 11 & $20 / 7-10$ & $20(1.1)$ & $\begin{array}{l}\text { symmetrical/unipa } \\
\text { rtite }\end{array}$ & absent & present (46) \\
\hline $\begin{array}{l}\text { Mesacanthion rigens } \\
\text { Gerlach, 1957* }\end{array}$ & 1680 & 52 & 3.3 & 14.6 & 4 & 8 & $25 / 8$ & $25(0.9)$ & $\begin{array}{l}\text { symmetrical/unipa } \\
\text { rtite }\end{array}$ & absent & present (70) \\
\hline $\begin{array}{l}\text { Mesacanthion southerni } \\
\text { Warwick, } 1973\end{array}$ & $\begin{array}{l}3280- \\
3900\end{array}$ & $\begin{array}{l}32.1- \\
33.9\end{array}$ & $\begin{array}{l}5.6- \\
5.8\end{array}$ & $\begin{array}{l}14.4 \\
- \\
14.9\end{array}$ & $4.2-4.5$ & 12 & $57 / 39-48$ & $\begin{array}{l}67-80 / 290- \\
320(1.2- \\
1.5 / 5.3-5.6 \\
\text { calc })\end{array}$ & $\begin{array}{l}\text { asymmetrical/bipa } \\
\text { rtite/striated }\end{array}$ & present (40-51) & present $(82-100)$ \\
\hline $\begin{array}{l}\text { Mesacanthion studiosum } \\
\text { Inglis, 1964* }\end{array}$ & $\begin{array}{l}5500- \\
5900\end{array}$ & $\begin{array}{l}48.3- \\
53.7\end{array}$ & $\begin{array}{l}4.1- \\
4.3\end{array}$ & $\begin{array}{l}16.0 \\
- \\
18.7\end{array}$ & $4.1-4.8$ & $19-20$ & $48-50 / 18-20$ & $\begin{array}{l}68-81(0.9- \\
1.0 \text { calc })\end{array}$ & $\begin{array}{l}\text { symmetrical/unipa } \\
\text { rtite }\end{array}$ & absent & present (129-159) \\
\hline $\begin{array}{l}\text { Mesacanthion } \\
\text { tenuicaudatum (Ssaweljev, } \\
\text { 1912) De Coninck \& } \\
\text { Schuurmans Stekhoven, }\end{array}$ & 6000 & $45-50$ & 5 & 22 & $\begin{array}{l}\text { not } \\
\text { measur } \\
\text { ed }\end{array}$ & $\begin{array}{l}\text { not } \\
\text { measured }\end{array}$ & not measured & $\begin{array}{l}45 \text { (adb not } \\
\text { given or } \\
\text { depicted) }\end{array}$ & $\begin{array}{l}\text { no depiction } \\
\text { ("chitinized") }\end{array}$ & "unclear" & present $(\sim 22.5)$ \\
\hline
\end{tabular}


Mesacanthion virile

(Ditlevsen, 1930) De

Coninck \& Schuurmans 4400

25

$\begin{array}{ll}5 & 17 \\ & \\ 4.5- & 11.7 \\ 5 & - \\ 12.9\end{array}$

not
measu

measur $16 \mathrm{calc}$

-61 calc

163 calc (adb

not given or

symmetrical/unipa

rtite

measured)

present (232 calc)

Mesacanthion jejuensi

2703- $\quad 35.6-$

3723

46.6

$4.0-5.7 \quad 11-15$

43-59/18-34

72-85 (1.5)

symmetrical/bipar

tite

present (39-50) present (136-171)

1

2 Table 2. Comparison of diagnostic morphological characters of all Mesacanthion species. Species with spicules shorter than 2 anal

3 body diameters marked with asterisk. Males only, morphometric values rounded. 